\title{
How Fair Use Can Help Solve The OrPhaN WORKS PROBLEM
}

\author{
Jennifer M. Urban ${ }^{\dagger}$
}

\begin{abstract}
Many works that libraries, archives, and historical societies would like to digitize are "orphan works," that is, works for which the copyright holder either is unknown or cannot be located after a diligent search. Due to copyright risk if an owner later shows up, nonprofit libraries and similar institutions have been reluctant to digitize and make these works available, greatly limiting access to important cultural and historical information. While a legislative fix may soon be proposed, this Article argues that legislation is not necessary to enable some uses of orphan works by nonprofit libraries and archives. Instead, U.S. copyright law's fair use doctrine, which allows certain unpermissioned uses of copyrighted works, provides a partial solution. Though it is an incomplete solution, fair use has some significant advantages over other approaches through which libraries and archives could make publicly beneficial uses of orphan works. Under fair use, there is no need to develop a licensing system, significantly reducing administrative and transactional costs, and eliminating socially wasteful license fees for works that are not on the market, and for which an owner is unlikely to exist. Second, fair use has the flexibility to accommodate change over time as libraries and archives discover the best ways to search for owners, preserve works, and make them available. Finally, allowing fair use of orphans by libraries and archives helps fulfill copyright's critical purposes of promoting the dissemination of knowledge and supporting speech and free expression.
\end{abstract}

(C) 2012 Jennifer M. Urban.

† Assistant Clinical Professor of Law, University of California, Berkeley School of Law. The author gratefully acknowledges the many thoughtful ideas and helpful comments of Ty Alper, Roxanna Altholz, Michelle Anderson, Michael Donaldson, James Grimmelmann, David Hansen, Edward Lee, Mark Lemley, Saira Mohammed, Pamela Samuelson, Jason Schultz, Christopher Sprigman, and Karen Tani, participants in the Orphan Works \& Mass Digitization: Obstacles \& Opportunities conference [hereinafter Berkeley Orphan Works Conference], and participants in the $12^{\text {th }}$ Annual Intellectual Property Scholars Conference. This Article is output of the Berkeley Digital Library Copyright Project, generously supported by funding from the Alfred P. Sloan Foundation. More information about the Berkeley Digital Library Project can be found at http://www.law.berkeley.edu/12040.htm. I especially thank Ana Enriquez for excellent research assistance. The thoughts contained in this Article represent my individual academic conclusions and opinions, and should not be attributed to any client I represent or the Samuelson Law, Technology \& Public Policy Clinic, which I direct. In addition, the University of California, where I am a faculty member, is a defendant in the Authors Guild, Inc. v. HathiTrust suit; however, I do not represent, and in no way speak for, the University of California or any other party in the case. 


\section{TABLE OF CONTENTS}

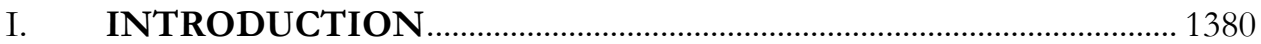

II. BRIEF BACKGROUND ON ORPHAN WORKS AND FAIR

USE

III. THE ORPHAN STATUS OF WORKS IS HIGHLY

RELEVANT TO THE NATURE-OF-WORK AND

MARKET-HARM FACTORS AND FAVORS FAIR USE

A. THE "NATURE” OF AN ORPHAN WORK ……………….................... 1392

1. Orphan Status as a Key Aspect of a Work's "Nature"................... 1395

2. Other Characteristics of Works in Library and Archive

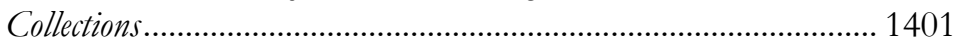

3. The Market-Harm Factor and Orphan Works .............................. 1402

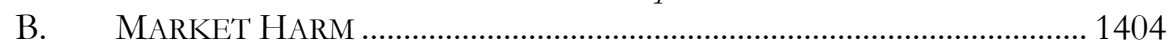

C. COLLECTIVE OR OTHER CENTRALly MANAGED LiCENSING ...... 1409

IV. NONCOMMERCIAL USE OF AND ACCESS TO ORPHAN WORKS VIA LIBRARIES AND ARCHIVES PROMOTES THE PROGRESS OF SCIENCE

A. THE Purpose AND CHARACTER OF NONPROFIT Library AND ARCHIVE USES OF ORPHANS FAVORS FAIR USE 1414

B. LiBRARY AND ARCHIVE DIGITIZATION OF ENTIRE ORPHAN WORKS OFTEN SHOULD NOT WEIGH AgAINST FAIR USE

UNDER THE AMOUNT-AND-SUBSTANTIALITY FACTOR . 1422

V. FURTHER STRENGTHENING FAIR USE'S APPLICATION 1425

VI. CONCLUSION 1427

\section{INTRODUCTION}

The twentieth century witnessed an explosion in creative production. By 1952, approximately 250,000 books were being published a year; by the year 2000 , it was one million. ${ }^{1}$ At the same time, new forms of mediaprofessional and amateur movies and photography, relatively inexpensive print media, and microforms, to name a few-developed and were used to create countless works, ranging from high art, to family photographs, to quotidian organizational records. Today, most such materials are only

1. Gabriel Zaid, So Many Books: Reading and Publishing in an Age of ABUndance 20-21 (1st ed. Paul Dry Books 2003). 
available to the public via the limited reach of physical collections. However, advances in digitization technologies offer tantalizing possibilities for preserving and providing greater access to our cultural and scientific heritage. Online access to digital copies of library and archive collections holds the promise of connecting many more readers with research, historical materials, and cultural ephemera.

Some digitization projects currently being undertaken by entities large and small illustrate the potential benefits of digitization programs. For example, the Library of Congress (LOC) makes millions of items available online through its American Memory project, a digitized collection of "written and spoken words, sound recordings, still and moving images, prints, maps, and sheet music that document the American experience." The Prelinger Archive collects ephemeral and home movies, and makes many of them available through the Internet Archive. ${ }^{3}$ The Civil Rights Movement Veterans website collects, digitizes, and puts online original documentation of the civil rights movement, from photographs to the organizational meeting minutes of the Student Nonviolent Coordinating Committee. ${ }^{4} \mathrm{~A}$ variety of other projects exist as well. ${ }^{5}$ Many of the works in these collections are rare, obscure, or simply specialized in nature. These works are unlikely to be commercially valuable or to circulate widely from traditional print

2. Mission and History (American Memory), Library OF CONGREss, http://memory.loc.gov/ammem/about/index.html (last visited July 28, 2012) [hereinafter Library of CONGress, Mission]; see, e.g., An American Time Capsule: Three Centuries of Broadsides and Other Printed Ephemera, LIBRARY OF CONGRESS, http://memory.loc.gov/ammem/ rbpehtml/ (last visited July 28, 2012).

3. Welcome to Prelinger Archives, INTERNET ARCHIVE, http://archive.org/details/ prelinger (last visited July 28, 2012).

4. Documents of the Southern Freedom Movement 1951-1968, Civil Rights MOVEMENT VETERANS, http://www.crmvet.org/docs/dochome.htm (last visited July 28, 2012); Photo Album, Civil Rights Movement Veterans, http://www.crmvet.org/images/img home.htm (last visited July 28, 2012). See also Bruce Hartford, Webmaster, Civil Rights Movement Veterans Website, Panel at Berkeley Orphan Works Conference: Who Wants to Make Use of Orphan Works and Why? (Apr. 12, 2012) (slides available at http://www.law.berkeley.edu/files/Hartford.pdf).

5. See, e.g., Patriotic Melodies, LiBrary OF CONGRESS, http://lcweb2.loc.gov/diglib/ ihas/html/patriotic/patriotic-home.html (last visited July 24, 2012) (one of many such projects at the Library of Congress); Michigan Digitization Project, MiCHIGAN LIBRARY, http://www.lib.umich.edu/michigan-digitization-project (last visited July 24, 2012); Allie Shay, Digitizing the Long Civil Rights Movement in North Carolina, Publishing THE LONG CiviL Rights MOVEMENT (Mar. 13, 2012), https://lcrm.lib.unc.edu/blog/index.php/2012/03/ 13/digitizing-the-long-civil-rights-movement-in-north-carolina. 
collections, ${ }^{6}$ but in the LOC's words, they can embody "a digital record of American history and creativity," and ultimately, "the 'nation's memory." ",

While works like these collectively comprise "the nation's memory," a significant proportion of such materials are also likely to be "orphan works"-presumptively copyrighted works for which no owner can be located. In such cases, there is no feasible way for libraries and archives to obtain permission to digitize and make the works available. By digitizing orphan works and putting them online, libraries and archives thus take the risk of a putative owner later appearing and suing. While the LOC and others have moved ahead with the digitization of some orphan works, the possibility of damages or injunctive relief still chills a great deal of potentiallysocially beneficial activity. ${ }^{8}$ For this reason among others, in 2006 the Copyright Office recommended legislation as a way to free up reuses of orphan works. While this legislation ultimately did not pass, the current Register of Copyrights, Maria Pallante, recently announced plans to pursue new orphan works legislation in Congress in the near future.

6. See ASs'N OF RES. LIBR., ARL STATISTICS 2008-2009, at 9 (2011), available at http://publications.arl.org/1h8eiv.pdf (showing low and decreasing circulation of print collections among research libraries). Decreasing circulation trends are even more pronounced when looking at individual collections. A study of the Cornell University Library, for example, shows that approximately fifty-five percent of its print monographs acquired since 1990 have never actually circulated. Cornell Univ. Libr., Report of the Collection Development Executive Committee Task Force on Print Collection Usage Cornell University Library 2, 13 (2010), available at http://staffweb.library.cornell.edu/ system/files/CollectionUsageTF_ReportFinal11-22-10.pdf; see also Nicholas Joint, Is Digitisation the New Circulation?: Borrowing Trends, Digitisation and the Nature Of Reading in US and UK Libraries, 57 LIBR. REV. 87, 90-92 (2008) (describing "digital natives[']" preference for access to digital versus print collections).

7. LIBRARY OF CONGRESS, Mission, supra note 2.

8. U.S. COPYRIGHT OfFICE, REPORT ON ORPHAN WORKS: A REPORT OF THE REGISTER OF COPYRIGHTS 15 (2006).

Many users of copyrighted works who have limited resources or are particularly risk-averse have indicated that the risk of liability for copyright infringement, however remote, is enough to prompt them simply to not make use of the work. Such an outcome is not in the public interest, particularly where the copyright owner is not locatable because he no longer exists or otherwise does not care to restrain the use of his work.

Id.

9. Maria A. Pallante, Orphan Works \& Mass Digitization: Obstacles \& Opportunities, 27 Berkeley TECH. L.J. 1251 (2012). As this Article went to press, the Copyright Office issued an initial Notice of Inquiry on the orphan works problem, confirming that the Office is undertaking a new process to delve into the problem. Notice of Inquiry: Orphan Works and Mass Digitization, 77 Fed. Reg. 64,555 (Oct. 22, 2012). 
This Article, however, explains why legislation should not be necessary to enable certain kinds of uses of orphan works. Specifically, it argues that courts should apply U.S. copyright law's fair use doctrine to allow the LOC and other nonprofit libraries and $\operatorname{archives}^{10}$ to digitize appropriately identified orphan works ${ }^{11}$ in their collections, and to publicly display these works to their patrons for noncommercial acts such as reading, viewing, conducting research, and developing scholarship. ${ }^{12}$ Some institutions have already been willing to move forward. It appears that the LOC, for example, has been relying on the fair use doctrine as a justification for digitizing and putting orphan works in its American Memory collections online for noncommercial use. ${ }^{13}$ Other libraries and archives have also made some orphan works in their collections available, despite the impossibility of clearing them. ${ }^{14}$ These

10. This is not to suggest that other types of entities or individuals are ineligible to claim fair use for digitizing orphans; this Article simply does not take up this question.

11. Orphan works, of course, must be properly identified as such. The Copyright Office Report identified the need for a reasonably "diligent search" to identify orphans, and the subsequent legislation introduced in Congress tracked that recommendation. U.S. COPYRIGHT OFFICE, REPORT ON ORPHAN WORKS, supra note 8, at 96; Shawn Bentley Orphan Works Act of 2008, S. 2913, 110th Cong. (2008); Orphan Works Act of 2008, H.R. 5889, 110th Cong. (2008); Orphan Works Act of 2006, H.R. 5439, 109th Cong. (2006). For purposes of this Article, I am leaving aside the details of what might constitute a reasonably diligent search and simply assuming that one has been done by the library or archive wishing to digitize a work, and that no owner was locatable. See infra note 61 for a further brief discussion.

12. Note that this Article takes no position about whether fair use is an appropriate solution for uses of orphan works outside of the nonprofit library and archival uses described above. For example, this Article does not consider making derivative works from orphan works, nor does it consider commercial uses at all. For some such uses, fair use may also appropriately play a role. For others, other proposed solutions-such as the original proposal by the U.S. Copyright Office to limit remedies for uses made after a reasonable search for the copyright owner-may instead be most appropriate.

13. See, e.g., American Women: Copyright and Other Restrictions, LiBRARY OF CONGRESS, http://memory.loc.gov/ammem/awhhtml/awcopy.html (last visited July 24, 2012) ("In [some] cases, the Library was unable to identify a possible rights holder and has elected to place some of those items online as an exercise of fair use for strictly non-commercial educational uses."); The Wilbur and Orville Wright Papers: Copyright and Other Restrictions, LIBRARY OF CONGRESS, http://memory.loc.gov/ammem/wrighthtml/wrightres.html (last visited July 24, 2012).

14. At the Berkeley Orphan Works Conference, for example, speakers from archives offered examples of a wide range of works they are making available in digital form. Brewster Kahle, Founder, Internet Archive; Kenneth Crews, Director, Columbia Copyright Advisory Office; Bruce Hartford, Webmaster, Civil Rights Movement Veterans Website; \& Rick Prelinger, Founder, Prelinger Archives, Panel at Berkeley Orphan Works Conference: Who Wants to Make Use of Orphan Works and Why? (Apr. 12, 2012) (slides available at http://www.law.berkeley.edu/11731.htm); see also Shay, supra note 5; About the Grateful Dead Archive, UNIVERSITY OF CALIFORNIA, SANTA CRUZ UNIVERSITY LibRARY, http://library.ucsc.edu/grateful-dead-archive/about (last visited July 24, 2012). 
activities do much to further the constitutional value of "promot[ing] the Progress of Science,"15 by freeing important features of the "nation's memory" and placing them into the hands of researchers, students, and other members of the citizenry, where they can illuminate our cultural history and support the further development of knowledge.

Indeed, given the lack of harm to owners who are unlocatable-who, indeed, may not exist at all-and the social benefits that would result from libraries and archives digitizing orphans and making them accessible, the conclusion that fair use covers such activities may seem obvious. This conclusion, however, is not accepted by all. The recent lawsuit brought by the Authors Guild against the HathiTrust illustrates this point. ${ }^{16}$ The case involved a "large scale digital preservation repository" 17 of nearly ten million books, some of which are orphans, run by a consortium of more than sixty research libraries and some of its member libraries. Among claims against various aspects of the HathiTrust's activities, the Authors Guild specifically argued that fair use does not justify the HathiTrust's digitization and access program for orphans. ${ }^{18}$ Additionally, libraries and archives themselves have expressed concerns about the perceived uncertainty of relying on fair use in order to provide access to orphans. ${ }^{19}$ As this Article was going to press, the

15. U.S. CONST., art. I, $\int 8, \mathrm{cl} .8$.

16. As this Article was going to press, the Southern District of New York released its decision in Authors Guild, Inc. v. HathiTrust, 11 CV 6351 HB, 2012 WL 4808939 (S.D.N.Y. Oct. 10, 2012), an important fair use case considering the mass digitization of (non-orphan) works. The Article has been updated to reflect relevant aspects of this decision.

17. Guidelines for Digital Object Deposit, HATHITRust Digital LiBrary, http://www.hathitrust.org/deposit_guidelines (last updated Dec. 10, 2011).

18. Memorandum of Law in Support of Plaintiffs' Motion for Partial Judgment on the Pleadings at 21-23, Authors Guild, Inc. v. HathiTrust, No. 11 Civ. 6351 (S.D.N.Y. Feb. 28, 2012). Note that the plaintiffs did not analyze fair use in detail in their motion for partial judgment on the pleadings, but instead argued that fair use can never apply to the defendants because it falls outside of the boundaries of $\int 108$ of the Copyright Act's specific exceptions for libraries. This argument seems fundamentally misguided; it appears to be incorrect in light of the plain language of $\int 108$ as well as the purposes animating both copyright law generally and fair use specifically. See Jonathan Band, The Impact of Substantial Compliance with Copyright Exceptions on Fair Use 3-5 (Nov. 30, 2011) (unpublished manuscript), available at http://papers.ssrn.com/sol3/papers.cfm?abstract_id=1966593. And in fact, as this Article was going to press, Judge Baer's decision in the HathiTrust case decisively dismissed it, stating, "Here, fair use does not undermine $\int 108$, but rather supplements it." Authors Guild, 2012 WL 4808939, at *8-9.

19. See, e.g., Prudence Adler, Brandon Butler, Patricia Aufderheide \& Peter Jaszi, FAir Use Challenges in ACADEmic AND Research Libraries 6, 13-15 (2010), available at http://www.arl.org/bm doc/arl_csm_fairusereport.pdf; Marc Parry, Out of Fear, Colleges Lock Books and Images Away from Scholars, CHrOnicLE HiGHER ED. (May 29, 2011), http://chronicle.com/article/Out-of-Fear-Institutions-Lock/127701/. 
HathiTrust case was decided in the trial court. ${ }^{20}$ Though the court did not reach the question of orphan works specifically, ${ }^{21}$ Judge Harold Baer decisively held that fair use protected several uses of works in the corpus by known authors made by the HathiTrust libraries. He also held that the digitization required to make those uses possible was fair. ${ }^{22}$

This Article demonstrates that courts should also consider it fair use for libraries and archives to make nonprofit uses of orphan works, including a broader array of uses than the court considered for the non-orphan works in the HathiTrust case. At its core, the Article posits three questions: First, should reproducing (by digitization or other means) an orphan work by a nonprofit library or archive for noncommercial, socially beneficial purposes-for example, preservation, education, access to knowledge, traditional forms of research and scholarship, and new forms such as text mining-be considered a fair use? Second, should making the copy available to patrons-for example, by posting it online for viewing-also be considered a fair use? More generally, the Article considers whether the fair use doctrine should do any additional work when the copyrighted work in question is an orphan.

I answer each of these questions in the affirmative. Although there is no directly analogous case on point ${ }^{23}$ and some aspects of the use-for example,

20. Authors Guild, Inc. v. HathiTrust, 11 CV 6351 HB, 2012 WL 4808939 (S.D.N.Y. Oct. 10, 2012).

21. Id. at $* 7-8$.

22. Id. at *9. These uses include digitization of the works for the purposes of search, preservation, and accessibility for patrons with print disabilities. $I d$. at $* 2$ (explaining the uses covered by the decision). These uses closely track some of the uses that I consider in Section IV.A, infra, and analyze as likely to be fair uses of orphans. As the first case to consider these uses by libraries, Judge Baer's decision is supportive of these aspects of my argument; as discussed further throughout the Article, the reasons why these uses are fair should apply with even greater force for orphans. It should be noted that the libraries' Orphan Works Program (OWP), which would have provided full-text access to works to library patrons, rather than the bare search result provided for all works, was not ripe to be adjudicated. $I d$. (describing the full-text access for patrons); $i d$. at *7-8 (dismissing claims at OWP as not ripe for adjudication). As such, the case does not decide whether the claim made in this Articlethat full-text access of true orphans should be considered fair use-is correct.

23. The Authors Guild, Inc. v. HathiTrust case may confront this question directly, but there is as yet no published opinion on point. The defendant libraries have indicated that they believe the HathiTrust orphan works program is justified under fair use. See Defendants' Joint Answer and Defenses at 23, Authors Guild, Inc. v. HathiTrust, No. 11 Civ. 6351 (S.D.N.Y. Dec. 2, 2011). Should this case result in a published opinion on the fair use question as it relates to orphans, it will likely shed substantial light on the issue of whether and how fair use might apply to making orphan works available within a research library community. As explained supra note $t$, the author is a faculty member at the 
using entire works - are sometimes thought to be disfavored under the fair use doctrine, close scrutiny of the most comparable cases and of the purposes animating the fair use doctrine supports finding fair use for a variety of typical uses of orphan works by libraries and archives.

Part II of this Article briefly introduces the fair use concept and discusses its overall place in the debate over orphan works. Part III explains why the orphan status of a work is highly relevant to the fair use analysis. While the second factor of the fair use statute-the "nature of the copyrighted work"- often has little significance, Section III.A argues that this second factor should have a prominent role in orphan works cases. This prominent role is necessary because the work's "nature" as an orphan both gives insight into the author's likely incentives for creating the work and reveals how its orphan status fundamentally skews the market for the work. As such, orphan works are analogous to the unavailable "out of print" works that Congress and a handful of courts have described as favorable candidates for fair use under the second factor. Section III.B considers the fourth factor; the effect of the use on the market for the copyrighted work. This Section argues that the market factor should weigh decidedly in favor of fair use in the case of orphan works, due to a lack of cognizable harm to orphan owners and to the societal cost of preventing use of these works. Libraries' and archives' use of orphans would generate significant social value from which society should benefit. Orphan works, however, represent a clear market failure: there is no realistic possibility of completing a rights clearance transaction, no matter how high the costs of that transaction, because one party to the transaction is missing. This scenario creates a public loss, and militates in favor of fair use. For nonprofit library and archive uses in particular, it also militates against creating artificial markets via collective licensing, due to the socially wasteful misallocation of resources such efforts would require.

Part IV explains that the purposes animating library and archive uses of orphans will generally favor fair use because these uses further the constitutional goals of copyright. Section IV.A considers the important first fair use factor - the "purpose and character" of the use-and the favored uses described in the preamble to $\int 107$. This Part explains that many purposes pursued by libraries and archives in digitizing and making available orphans are favored under both the preamble and the purpose factor, and go far to fulfill copyright's constitutional purpose to promote progress more generally. Section IV.B contemplates the third fair use factor-the "amount

$\overline{\text { University of California, Berkeley, but does not represent, and does not speak, for any party }}$ involved in this case. 
and substantiality" of the portion of the copyrighted work that was used. While the library and archive uses considered here would surely involve some entire works, a fact that is often thought to disfavor fair use, courts now assess the amount factor in light of the purpose for which the work is used. The socially beneficial purposes_-such as preservation, research, and education-for which libraries and archives are likely to copy orphans will often demand reproduction of entire works. Combined with the fact that using entire orphan works is no more likely to harm a nonexistent market than use of only parts of those works, this factor should often be found, at worst, neutral to a defendant claiming fair use.

Part $\mathrm{V}$ describes additional considerations that may be helpful for libraries and archives that choose to rely on fair use. Part VI concludes.

Note that this Article takes no position about whether fair use is an appropriate solution for uses of orphan works outside of the nonprofit library and archival uses described above. For example, it does not consider making derivative works from orphan works, nor does it consider commercial uses at all. For some such uses, fair use may also appropriately play a role. For others, different proposed solutions-such as the original proposal by the U.S. Copyright Office to limit remedies for uses made after a reasonable search for the copyright owner-may instead be most appropriate.

\section{BRIEF BACKGROUND ON ORPHAN WORKS AND FAIR USE}

"Orphan works" are those presumptively copyrighted works for which the owner cannot be found. ${ }^{24}$ There is broad agreement that orphans present

24. This definition is taken from the U.S. Copyright Office's 2006 Report on Orphan Works. U.S. COPYRIGHT OFFICE, supra note 8 , at 1 . This definition is widely accepted by policymakers and academics. See, e.g., Proposal for a Directive of the European Parliament and of the Council on Certain Permitted Uses of Orphan Works, COM (2011) 289 (May 24, 2011), available at http://eur-lex.europa.eu/LexUriServ/LexUriServ.do?uri=COM:2011:0289:FIN:EN:PDF [hereinafter EU ORPHAN WORKS Directive]; COMIté DES SAgES, THE NeW RENAISSANCE 16 (2011), available at http://ec.europa.eu/information_society/ activities/digital_libraries/doc/refgroup/final_report_cds.pdf; EUROPEAN DIGITAL LIBRARIES, Final Report on Digital PRESERVATION, OrPHAN WORKS, AND OUT-OF-PRint Works (2008), available at http://ec.europa.eu/information_society/activities/digital_libraries/doc/hleg/ reports/copyright/copyright_subgroup_final_report_26508-clean171.pdf; IAN HARGREAVES, Digital Opportunity: A Review of Intellectual Property and Growth 38-40 (2011), available at http://www.ipo.gov.uk/ipreview-finalreport.pdf; Olive Huang, U.S. Copyright Office Orphan Works Inquiry: Finding Homes for the Orphans, 21 BERKELEY TECH. L.J. 265, 265 (2006); Bernard Lang, Orphan Works and the Google Book Search Settlement: An International Perspective, 55 N.Y.L. SCH. L. REV. 111, 116 (2010); Pamela Samuelson, The Google 
a serious and growing issue for library and archive digitization projects. ${ }^{25}$ In theory, any work could be an orphan, but the likelihood of orphan status increases with age. As time passes, information about the ownership of some works fades, and the task of connecting a work to its owner becomes more difficult, more costly, and in some cases impossible-making "clearing" the works by obtaining permissions also impossible. As copyright has changed over time, the likelihood of works becoming separated from owners has grown. For example, longer and longer copyright terms increase the likelihood that works will become disconnected from their owners. And as discussed below, in passing the 1976 Copyright Act, Congress recognized that the Act's abolishment of copyright renewal requirements might increase the number of works covered by copyright even where there is lack of a commercial interest that would encourage their exploitation. Today, though it is difficult to determine the number of orphan works, it is clear that there are a great many, at least hundreds of thousands and perhaps many millions. ${ }^{26}$

If these works cannot be digitized for preservation and for access by the public, then their "orphaning" creates a large social cost and a significant drag on the copyright system's purpose to encourage the spread of knowledge. Many could disappear before they can enter the public domain and freely be repurposed. Liberating ${ }^{27}$ these works from copyright limbo, on the other hand, would have great social benefit, both for today's public and for tomorrow's generations of scholars, students, and citizens. Accordingly, an international consensus has recently developed that there is an urgent need to address the orphan works problem. ${ }^{28}$

Books Search Settlement as Copyright Reform, Wis. L. REV. 479, 483 (2011). But see Kahle v. Gonzales, 487 F.3d 697, 698 (9th Cir. 2007) (using "orphan" as plaintiffs suggested, to mean "works that allegedly have little or no commercial value but remain under copyright protection").

25. See David R. Hansen, Orphan Works: Causes of the Problem 1 (Berkeley Digital Library Copyright Project, White Paper Nov. 3, 2012), available at http://papers.ssrn.com/sol3/ papers.cfm?abstract_id=2038068; HARGREAVES, supra note 24; COMITÉ DES SAGES, supra note 24; U.S. COPYRIGHT OFFICE, supra note 8.

26. For example, estimates of the number of orphans in the Google Book Search corpus vary from a minimum of hundreds of thousands to several millions. See John P. Wilkin, Bibliographic Indeterminacy and the Scale of Problems and Opportunities of "Rights" in Digital Collection Building (Council on Library \& Ress. Ruminations No. 1, 2011), available at http://www.clir.org/pubs/ruminations/01wilkin/wilkin.html/wilkin.pdf.

27. See Lydia Pallas Loren, Abandoning the Orphans: An Open Access Approach to Hostage Works, 27 BERKELEY TECH. L.J. 1431 (2012).

28. See EU ORphan Works DiRECTIVE, supra note 24; HARgreAVES, supra note 24; COMITÉ DES SAGES, supra note 24. 
There is less agreement on a proposed solution to the problem. ${ }^{29}$ Ideas vary, but cluster around two main themes: legislative fixes that limit the remedies available to copyright owners who resurface even after a follow-on user has completed a "diligent search" and failed to find them; or license schemes administered by collecting societies or other central bodies. ${ }^{30}$ These are generally all worthy ideas, though each has its limitations. ${ }^{31}$

This Article contends that the existing doctrine of fair use provides a way to broaden access to orphans. Fair use is one of the most distinctive features of U.S. copyright law. ${ }^{32}$ It stems from and supports copyright's fundamental purpose to "promote the Progress of Science" 33 by balancing incentives to create original works with the social benefits that flow from the broad dissemination of those works, and by preserving fundamental First Amendment rights and free expression. ${ }^{34}$

29. Proposed solutions to the orphan works problem are quite varied. Some, such as the Copyright Office's remedies limitation approach, are quite simple. See U.S. COPYRIGHT OFFICE, supra note 8, at 115-21. Others, such as proposals for extended collective licensing or other transaction regimes, could prove to be highly complex, but they create additional certainty for users. See generally David R. Hansen, Orphan Works: Mapping the Possible Solution Spaces (Berkeley Digital Library Copyright Project, White Paper No. 2, 2012), available at http://papers.ssrn.com/sol3/papers.cfm?abstract_id=2019121 (describing a variety of proposals).

30. Hansen, supra note 29 , at $1-2$.

31. A full discussion of other proposed solutions is outside the scope of this Article. I discuss some of the limitations of licensing schemes infra Section III.A.3. Remedies limitations and registries or other formalities each have strong potential to effectively attack some aspects of the problem. Remedies limitations could effectively reduce the fear of downside risk, allowing more use of orphans See, e.g., U.S. COPYRIGHT OFFICE, supra note 8, at 115-21. Formalities-type solutions could directly address the problem by preventing the creation of orphans in the first place: a system that encourages or requires registering a work and its owner in a central database could go far toward keeping works connected to their owners. A main limitation of each of these proposals is the political will that would be required to muster the necessary legislative changes; however, there are some promising signs in recent national and international discussions. See STEF VAN GOMPEL, FormalitieS in Copyright Law: An Analysis of Their History, Rationales and Possible FUTURE (2011). In addition, the U.S. Copyright Office recently issued a new Notice of Inquiry on the orphan works issue." See supra note 9.

32. Fair use has been a feature of U.S. copyright law since at least 1841, when Justice Story drafted Folsom v. Marsh, 9 F. Cas. 342 (C.C.D. Mass. 1841) (No. 4901), but the fundamental ideas behind it were introduced into copyright law by English courts of equity at least a hundred years earlier. See, e.g., Gyles v. Wilcox, (1740) 26 Eng. Rep. 489 (Ch.) 490 (discussing "fair abridgment"). In the 1976 Copyright Act, Congress restated the doctrine in statutory form in $₫ 107.17$ U.S.C. $\int 107$ (2010).

33. U.S. CONST., art. I, $\int 8$, cl. 8.

34. Eldred v. Ashcroft, 537 U.S. 186, 219-20 (2003) (characterizing fair use as providing "traditional First Amendment safeguards"). Fair use's purpose in promoting and protecting expression is described in numerous cases. See, e.g., id.; Campbell v. Acuff-Rose 
Unlike other exceptions and limitations in the Copyright Act, ${ }^{35}$ and in most foreign copyright regimes, ${ }^{36}$ fair use is not limited to specific actors or specific uses. Rather, it is an "equitable rule of reason," 37 developed by courts and embodied in $\int 107$ 's familiar four factors: What is the purpose of the use? What is the nature of the allegedly infringed work? What is the amount and substantiality of what has been taken from the allegedly infringed work? And what is the effect of the use on the market for the allegedly infringed work $?^{38}$ Courts apply these factors on a case-by-case basis. Because of its equitable nature, fair use can flexibly accommodate changes in both copyrighted works and uses of those works over time. ${ }^{39}$ Accordingly, fair use

Music, Inc., 510 U.S. 569 (1994); Harper \& Row, Publishers, Inc. v. Nation Enters., 471 U.S. 539 (1985); Perfect 10, Inc. v. Amazon.com, Inc., 508 F.3d 1146, 1163 (9th Cir. 2007).

35. For example, $\ 108$ 's protections for certain library and archival uses are contingent on various requirements, including whether the library or archive is open to the public and how the library distributes the copies it makes, and $\int 110$ 's exception is limited to "face-toface teaching" at a "nonprofit educational institution, in a classroom or similar place devoted to instruction." 17 U.S.C. SS 108, 110 (2010).

36. Other countries do have limitations protecting socially beneficial uses, but they tend to enumerate specific protected activities rather than using a generalized standard. See, e.g., Pamela Samuelson, Unbundling Fair Uses, 77 Fordham L. REV. 2537, 2540 n.17 (2009) (citing the Council Directive 2001/29/EC, art. 5, On the Harmonization of Certain Aspects of Copyright and Related Rights in the Information Society, 2001 O.J. (L 167) 10 (establishing allowable exceptions and limitations to copyright in the EU)). For examples of more recent flexible limitations, see infra note 219.

37. H.R. REP. NO. 94-1476, at 65 (1976).

38. 17 U.S.C. $\int 107$ (2010). In its entirety, \ 107 reads:

Notwithstanding the provisions of $\iint 106$ and 106A, the fair use of a copyrighted work, including such use by reproduction in copies or phonorecords or by any other means specified by that section, for purposes such as criticism, comment, news reporting, teaching (including multiple copies for classroom use), scholarship, or research, is not an infringement of copyright. In determining whether the use made of a work in any particular case is a fair use the factors to be considered shall include-

(1) the purpose and character of the use, including whether such use is of a commercial nature or is for nonprofit educational purposes;

(2) the nature of the copyrighted work;

(3) the amount and substantiality of the portion used in relation to the copyrighted work as a whole; and

(4) the effect of the use upon the potential market for or value of the copyrighted work.

The fact that a work is unpublished shall not itself bar a finding of fair use if such finding is made upon consideration of all the above factors.

Id.

39. See, e.g., Sony Corp. v. Universal City Studios, Inc., 464 U.S. 417, 447-56 (1984) (accommodating "time-shifting" of televisions shows via video tape recorders); Sega Enters. 
is especially well-suited to copyright problems that arise from evolving situations, such as the orphan works phenomenon. ${ }^{40}$

It is thus unsurprising that both the Copyright Office and Congress took care not to disturb fair use when designing the 2008 proposed legislation for orphan works. The Copyright Office's report "stress[ed] that the presence of an orphan works provision should not act as a substitute or replacement for fair use." 41 The bills introduced in both the House and Senate included savings clauses making clear that fair use would not be affected by orphan works legislation, and explicitly referred to the user of orphan works as the "infringer," rather than the "user" or some other term. ${ }^{42}$ This reference was, in part, an attempt to make clear that those engaging in fair uses of orphan works-who are not infringers-were not limited by the strictures of the proposed statute. ${ }^{43}$ It also sought to clarify that the fair use doctrine overall would not be inadvertently limited by it. ${ }^{44}$

v. Accolade, Inc., 977 F.2d 1510, 1520-28 (9th Cir. 1992) (accommodating "reverse engineering" of computer programs); Kelly v. Arriba Soft Corp., 336 F.3d 811, 817-22 (9th Cir. 2003) (accommodating an image search engine).

40. As works in the collections of libraries and archives age, it seems likely that they will simultaneously become more likely to become "orphaned" and in greater need of preservation. At the same time, new methods of digitizing, organizing, and making works available are likely to arise, as are new uses of digital corpuses. Fair use's flexibility in accommodating such developments makes it, where it applies, especially appropriate for addressing orphan works issues over time.

41. U.S. COPYRIGHT OFFICE, supra note 8, at 56.

42. Shawn Bentley Orphan Works Act of 2008, S. 2913, 110th Cong. \514(d) (2008); Orphan Works Act of 2008, H.R. 5889, 110th Cong. \514(e) (2008); Orphan Works Act of 2006, H.R. 5439, 109th Cong. \514(c) (2006).

43. For example, both the House and Senate 2008 bills required a user of an orphan work to designate the orphan work with a symbol, to provide attribution as possible, and to negotiate in good faith with later-appearing owners. S. 2913 \514(b)(1); H.R. 5889 $\int 514(\mathrm{~b})(1)$.

44. This observation proceeds directly from my participation in discussions around the proposed legislation; it is one interpretation that was offered during discussions among stakeholders. As an interpretation, this follows directly from the language of the Copyright Act. 17 U.S.C. $\int 107$ (2006) (stating "[fair use] is not an infringement of copyright"); 17 U.S.C. $\int 106$ (2006) (stating that the copyright owner's exclusive rights under Title 17 are "subject to" \$ 107). It is, however, important to note that the question of whether a fair user is an "infringer" is a matter of robust debate. PETER JASZI \& PATRICIA AUfDERHEIDE, Reclaiming Fair Use: How to Put BALANCE BACK IN COPyright (2011). Further, as a matter of procedure, courts often treat fair use as an affirmative defense to an infringement-in other words, an excused infringement. See Campbell v. Acuff-Rose Music, Inc., 510 U.S. 569, 590 (1994); Perfect 10 Inc. v. Amazon.com Inc., 508 F.3d 1146, 1163 (9th Cir. 2007); U.S. COPYRIGHT OFFICE, supra note 8, at 56 ("We stress that the presence of an orphan works provision should not act as a substitute or replacement for fair use.”). 
Indeed, in its discussion of the 1976 Copyright Act, ${ }^{45}$ Congress both recognized the problems inherent in "t[ying] up a substantial body of material that is probably of no commercial interest" that would likely arise under the Act's shift away from renewal requirements, and offered fair use as an ameliorator, stating in the House report:

It is true that today's ephemera represent tomorrow's social history, and that works of scholarly value, which are now falling into the public domain after 28 years, would be protected much longer under the bill ... it is important to realize that the bill would not restrain scholars from using any work as source material or from making "fair use" of it .... ${ }^{46}$

This dual recognition of a specific problem and the appropriateness of fair use in addressing it should further lead us to take fair use especially seriously in orphan works cases.

It also brings us to the broader question addressed in this Article: whether the orphan status of a work is especially relevant for fair use. The following discussion argues that such status is relevant, focusing first on the "nature" of an orphan work in a library or archive collection, and second on the follow-on effects of that orphan status for fair use's market-harm analysis.

\section{THE ORPHAN STATUS OF WORKS IS HIGHLY RELEVANT TO THE NATURE-OF-WORK AND MARKET- HARM FACTORS AND FAVORS FAIR USE}

\section{A. The "NATURE” OF AN ORPHAN WOrK}

The U.S. copyright law's fair use provision directs courts to consider "the nature of the copyrighted work" that the plaintiff claims was infringed. ${ }^{47}$ According to Judge Leval, this factor "concerns itself with protecting the incentives of authorship. It implies that certain types of copyrighted material are more amenable to fair use than others." 48 In evaluating the nature of a work, courts have sometimes limited the inquiry to whether the work is more

45. Copyright Act of 1976, Pub. L. No. 94-553, 90 Stat. 2541 (codified as amended at 17 U.S.C. SS 101-805).

46. H.R. ReP. NO. 94-1476, at 136 (1976). As the Copyright Office noted in its Report on Orphan Works, "Congress recognized the problem [with extending copyright terms and abolishing renewal requirements], but considered it to be outweighed by the many benefits of the new system," such as removing the "traps for the unwary" created by formalities requirements. U.S. COPYRIGHT OFFICE, supra note 8, at 43.

47. 17 U.S.C. $\int 107(2)(2010)$.

48. Pierre N. Leval, Toward a Fair Use Standard, 103 HARV. L. REV. 1105, 1116 (1990). 
factual or more creative, and whether it has been published or remains unpublished. ${ }^{49}$ The usual outcome of this inquiry is that fair use of a work is easier to establish when the work is factual rather than creative, ${ }^{50}$ and when it has been published rather than remaining unpublished, though the latter depends heavily on the factual context. ${ }^{51}$ In addition, courts have sometimes focused the nature factor on whether the work was out-of-print and unavailable on the market. ${ }^{52}$

It is unusual to begin a fair use analysis with this factor. The nature-ofwork factor is widely understood to weigh lightly in most fair use cases, and courts often truncate their discussion of this factor ${ }^{53}$ so that it has little significance in the context of the broader analysis. ${ }^{54}$ But the nature factor is important in some cases, notably Harper \& Row $v$. Nation Enterprises, in which the work's unpublished status was tied to a valuable interest in first serialization, ${ }^{55}$ and in Sega v. Accolade and related cases, in which the software programs at issue contained unprotected ideas that "afford[ed] them a lower degree of protection than more traditional literary works." Additionally, some commentators, notably Pierre Leval and Robert Kasunic, have proposed that the nature-of-work factor should receive deeper consideration more generally. ${ }^{56}$ Judge Leval argues that inquiry into the nature of the copyrighted work should give insight into copyright's goal "to stimulate authorship for the public edification" by "determ[ining] whether the work is the type of material that copyright was designed to stimulate, and whether the secondary

49. See Campbell v. Acuff-Rose Music, Inc., 510 U.S. 569, 586 (1994); Stewart v. Abend, 495 U.S. 207, 237-38 (1990); Harper \& Row Publishers, Inc. v. Nation Enters., 471 U.S. 539, 563-64 (1985); Barton Beebe, An Empirical Study of U.S. Copyright Fair Use Opinions: 1978-2005, 156 U. PA. L. REV. 549, 610-15 (2008).

50. Beebe, supra note 49 , at 611 .

51. Harper \& Row, 471 U.S. at 564; Beebe, supra note 49, at 612-15.

52. Harper \& Row, 471 U.S. at 553 ("If the work is 'out of print' and unavailable for purchase through normal channels, the user may have more justification for reproducing it.") (quoting S. Rep. No. 94-473, at 64 (1975)); cf. Peter Letterese \& Assocs., Inc. v. World Inst. of Scientology Enters., 533 F.3d 1287, 1313-14 (11th Cir. 2008). But see Basic Books, Inc. v. Kinko’s Graphics Corp., 758 F. Supp. 1522, 1533 (S.D.N.Y. 1991).

53. See Robert Kasunic, Is That All There Is? Reflections on the Nature of the Second Fair Use Factor, 31 COLUM. J.L. \& ARTS 529, 529 (2008); Leval, supra note 48, at 1116 ("The nature of the copyrighted work is a factor that has been only superficially discussed and little understood."). According to Barton Beebe, “[d]espite \107's command that 'the factors to be considered shall include' factor two, $17.7 \%$ of the $\ldots$ opinions [applying $\int 107$ ] failed even to refer to the factor, while an additional $6.5 \%$ did so only to call it irrelevant." Beebe, supra note 49, at 610 .

54. Melville B. Nimmer \& David Nimmer, Nimmer on Copyright $\int 13.05$ (2011).

55. Harper \& Row, 471 U.S. at 564 (noting the effect on plaintiff's right of first serialization meant that the unpublished nature of the work weighed heavily against fair use).

56. Leval, supra note 48, at 1116-22; Kasunic, supra note 53, at 530. 
use ... would interfere significantly with the original author's entitlements." 57 Kasunic agrees, though he argues that a better form of this question is "whether copyright might have reasonably encouraged or provided an incentive for an author to create the work" taking into account the norms and customs of the relevant genre. ${ }^{58}$

This more probing approach to the nature-of-work factor has much to recommend it, especially in orphan works cases. In general, such an inquiry can illuminate whether copyright's creation and dissemination goals are furthered by allowing the copyright owner full control or instead allowing fair use, and relatedly, whether the defendant's use is likely to invade a "traditional, reasonable, or likely to be developed" market under the marketharm factor. ${ }^{59}$ In the specific case of orphan works, the fact that a work has been orphaned-that is, disconnected from its owner and thus made unavailable on the market - could easily be considered as one important aspect of the work's "nature" in fair use cases. First, the "orphan" aspect of a work's nature strongly suggests that it was not sufficiently available on the market to support copyright's dissemination goals. As such, considering orphan status under this factor would be analogous to some courts' treatment of works whose nature includes being unavailable on the market. ${ }^{60}$ Second, recognizing the "Orphan" aspect of a work in question should prompt additional inquiries into the work's nature, such as whether or not it was created in response to copyright incentives. While the fact that a work is an orphan is not by itself sufficient to conclude whether a work was created in response to copyright incentives, such status is evidence that should provoke further inquiry. Some relevant inquires are described in more detail below.

Beginning with the nature-of-work factor here can thus give insight into the importance for fair use cases of a work's orphan status. More broadly, this factor can also shed light on the importance of a variety of other characteristics of the "nature" of orphan works that are likely to be in library and archival collections. Overall, a work's "orphaned" status provides a distinct and strong argument for giving considerable weight to this factor in any case involving orphans. The strength of this argument is intensified by other aspects of the nature of many works in library and archive collections. Armed with insight from this inquiry, it is then straightforward to proceed to considering the market-harm and purpose questions.

57. Leval, supra note 48, at 1118-19.

58. Kasunic, supra note 53, at 540.

59. Am. Geophysical Union v. Texaco Inc., 60 F.3d 913, 930 (2d Cir. 1994).

60. See infra note 69 and accompanying text. 


\section{Orphan Status as a Key Aspect of a Work's "Nature"}

The signature characteristic of an orphan work's "nature" is that its owner cannot be found. ${ }^{61}$ Whether the missing owners are defunct organizations, anonymous apparatchiks, or simply individual creators lost in the sands of time, they are by definition no longer tied to the work, ${ }^{62}$ and it is

61. A full discussion of how best to identify orphans is outside of the scope of this Article. In brief, however, there is broad consensus around conducting a threshold "diligent search" for copyright owners. COPYRIGHT OFFICE, supra note 8, at 5-6 ("Almost every commenter who advocated a limitation-on-remedies system agreed that a fundamental requirement for designation of a work as orphaned is that the prospective user have conducted a search for the owner of the work, and that the search results in the owner not being located. The commenters differed in the types of searches they would consider adequate.”); Shawn Bentley Orphan Works Act of 2008, S. 2913, 110th Cong., at 6-7 (2008); EU ORPHAN WORKS DIRECTIVE, supra note 24, at 10. Details about what might constitute a reasonably diligent search are a topic for another paper. For the purposes of this Article, I have assumed that "orphan" means that a search that is reasonable under the circumstances has occurred, and no owner has been found.

However, it is important to note that, without care, search costs could easily become unreasonably high, quashing the incentive or ability to make a socially beneficial use. Search costs could, in fact, quickly could become exceptionally burdensome, as a search for an unlocatable owner is, at a basic level, an attempt to prove a negative (that no one exists or that the identified owner cannot be found) that may be unprovable. Any solution to the orphan works problem, including fair use, cannot require searches so onerous as to undermine the benefits of the solution by making costs so high as to dampen incentives to use orphans or prohibit the possibility entirely. This is obviously especially important for nonprofit libraries and archives, which have limited budgets, forcing them to be costsensitive.

62. Of course, if a court is considering fair use, then this means that a putative owner has appeared and claimed the work; as such, it may no longer be an orphan. This occurrence prompts two observations. First, courts should take care to address the question of ownership early in the proceedings. In infringement cases, copyright holders bear the burden of proving that they own the work in question, and it will be particularly important to address this question for an owner who was not locatable after a reasonable search. Plaintiffs do make mistakes in claiming ownership. See, e.g., Cambridge Univ. Press v. Becker, 863 F. Supp. 2d 1190 (N.D. Ga. 2012) (holding that plaintiffs could not prove ownership for the works at issue in multiple claimed infringements). Second, assuming that the plaintiff is indeed the correct owner, then the effect of the work's orphan status on the application of the fair use doctrine should be considered for any use of the work up until the owner reappeared to claim the work. Once the owner is back in the picture, then the question becomes whether the use should be licensed or still is fair. Note also that plaintiffs have already attempted to address orphan works even where the owner has not come forth. While they were unsuccessful in doing so, the Authors Guild $v$. HathiTrust organizational plaintiffs claimed associational standing on behalf of all of their members. This scenario is another way orphan owners might "appear" before a court. Authors Guild, Inc. v. HathiTrust, 11 CV 6351 HB, 2012 WL 4808939, at *4-7 (S.D.N.Y. Oct. 10, 2012). Plaintiffs may also attempt to bring class actions on behalf of a class that includes putative orphan owners. See, e.g., Authors Guild, Inc. v. Google, Inc., Case No. 05 CV (S.D.N.Y. Feb. 13, 2012). 
likely ${ }^{63}$ that the work is no longer-if it ever was-tightly connected to their economic interests. Courts should recognize the nature-of-work factor's value in informing their understanding of at least two key attributes of orphan works: first, that their participation in a market that might be harmed by allowing fair use is unlikely, at best; and second, whether the likely motivations behind the work's creation stemmed from copyright's economic incentives.

During the Copyright Office proceedings on orphan works, commenters pointed out that the fact that a work's owner is missing will often indicate that the work has low, or no, market value to those owners. ${ }^{64}$ After all, a work that cannot be connected to its owner after a diligent search has a high probability of having been economically abandoned. ${ }^{65}$ This feature of orphan works is relevant to whether the use would "interfere significantly with the original author's entitlements" $" 66$ and whether such use is likely to invade a "traditional, reasonable or likely to be developed" ${ }^{67}$ market under the marketharm factor. As discussed in more detail in Section III.B, infra, where a work

63. There are no doubt exceptions. Photographs, for instance, routinely lack author information. During the discussions about U.S. orphan works legislation, professional photographers expressed concern that orphan works legislation could unjustly deprive them of their ability to appropriately control the copyrights in their photographs because they are easily disassociated from the works. Response of American Society of Media Photographers to Orphan Works Notice of Inquiry, Mar. 25, 2005, Comment OW0668 at 1, available at http://www.copyright.gov/orphan/comments/OW0668-ASMP.pdf; Response of Professional Photographers of America to Orphan Works Notice of Inquiry, Mar. 25, 2005, Comment OW0642 at 1, available at http://www.copyright.gov/orphan/comments/ OW0642-PPA.pdf. As better search mechanisms - especially visual matching technologiesdevelop, this understandable concern may be addressed over time. More generally, in such cases courts should conduct an inquiry into the characteristics of the work that could illuminate the reason for its lack of connection with an owner. While professional photographs may have economic value, untold thousands of amateur "snaps" do not, and were very likely created in response to motivations other than copyright incentives. In some cases, seeing the difference will be straightforward-for example, an industrial photograph created by a defunct company, apparently orphaned because the company no longer exists and most likely never had a copyright-based interest in the photo-some cases less so. The equitable inquiry of fair use is especially well-suited to such tasks.

64. See generally Response of Public Knowledge to Orphan Works Notice of Inquiry, Mar. 25, 2005, Comment OW0629 at 8, available at http://www.copyright.gov/orphan/ comments/OW0629-PublicKnowledge.pdf; COPYRIGHT OFFICE, supra note 8, at 84.

65. Loren, supra note 27; Aryeh L. Pomerantz, Obtaining Copyright Licenses by Prescriptive Easement: A Solution to the Orphan Works Problem, 50 JuRIMETRICS J. 195 (2010); Matthew W. Turetzky, Note, Applying Copyright Abandonment in the Digital Age, 2010 DuKE L. \& TECH. Rev. 19 (2010); Megan L. Bibb, Note, Applying Old Theories to New Problems: How Adverse Possession Can Help Solve the Orphan Works Crisis, 12 VAND. J. ENT. \& TECH. L. 149 (2009).

66. Leval, supra note 48, at 1118-19.

67. Am. Geophysical Union v. Texaco Inc., 60 F.3d 913, 930 (2d Cir. 1994). 
has been left orphaned, such an invasion is very unlikely. Relatedly, orphan status indicates that the work is unlikely now to be disseminated to the public by its owner. As such, if libraries and archives can make the works available through fair use, it will advance knowledge without undermining markets for the works.

This analysis is in line with some courts' treatment of works that are unavailable on the market, as orphans by definition are. In the Senate Report accompanying the 1976 Act, Congress indicated that where a work "is 'out of print' and unavailable for purchase through normal channels, the user may have more justification for reproducing it than in the ordinary case." ${ }^{, 68} \mathrm{~A}$ handful of courts have followed this reasoning in applying the nature-ofwork factor to works unavailable on the market. ${ }^{69}$ The same reasoning applies to orphans, and perhaps with additional force to those orphans that were never presented to the public in the first place. ${ }^{70}$ The caselaw does rightly distinguish between works that no longer enjoy economic value or

68. S. Rep. No. 94-473, at 64 (1975).

69. See, e.g., Hofheinz v. A \& E Television Networks, 146 F. Supp. 2d 442, 447-48 (S.D.N.Y. 2001) (applying this reasoning to the use of a trailer for a film released almost fifty years earlier and not itself available on the market and finding that the second factor favored fair use); Maxtone-Graham v. Burtchaell, 803 F.2d 1253, 1264 n.8 (2d Cir. 1986) (stating that "[a] key, though not necessarily determinative, factor in fair use is whether or not the work is available to the potential user" and citing the Senate Report); S. Rep. No. 94-473, at 64 (1975) ('If the work is 'out of print' and unavailable for purchase through normal channels, the user may have more justification for reproducing it than in the ordinary case.”); H.R. Rep. No. 94-1476, at 67 (1976). But see Am. Geophysical Union, 60 F.3d at 931.

70. Arguably, the public's loss is greater when works are never available at all than when some copies-even if they are rare-have been injected into commerce. Of course, the countervailing argument, which held sway in courts until Campbell v. Acuff Rose and Congress' amendment of $\int 107$, is that follow-on users' fair use rights are circumscribed in unpublished works, due to copyright holder's interest in determining when first publication should occur. Judge Leval and others roundly criticized over-weighting a work's unpublished status in the fair use analysis and, following Campbell, courts began to engage in more careful analysis of this attribute of a work. Leval, supra note 48, at 1122 ("The fact that a document is unpublished should be of small relevance unless it was created for or is on its way to publication."); cf. 17 U.S.C. \ 107 (2010) (“The fact that a work is unpublished shall not itself bar a finding of fair use if such finding is made upon consideration of all the [fair use] factors.”); Campbell v. Acuff-Rose Music, Inc., 510 U.S. 569, 577-78 (1994) (stating that "the task is not to be simplified with bright-line rules," and "[a]ll [factors] are to be explored, and the results weighed together, in light of the purposes of copyright"). But see Harper \& Row Publishers, Inc. v. Nation Enters., 471 U.S. 539, 564 (1985) (noting that "the author's right to control the first public appearance of his expression weighs against such [fair] use of the work before its release" and stating that "[a] use that so clearly infringes the copyright holder's interests in confidentiality and creative control is difficult to characterize as "fair"). For orphans, specifically, as no owner can be found to give permission to publish, the public's loss appears particularly great, with little to no corresponding harm to the owner. 
whose authors have left them to languish ${ }^{71}$ and works that have been purposely withheld from the market by the copyright owner. ${ }^{72}$ This latter set of works enjoys the full protection of copyright, and their unavailability on the market will not weigh in favor of fair use. ${ }^{73}$ This latter reasoning might apply, for example, where a work's owner is locatable but recalcitrant or unresponsive. In such cases, however, the work is not orphaned.

Along with other aspects of its "nature," the "orphaned" status of a work may also provide insight into whether traditional copyright incentives supplied an impetus to create the work, and thus whether allowing fair use would damage future incentives. Of course, exactly how much a work's orphan status reveals about the creation impetus will depend on the entire set of specific characteristics of that work. However, given the fact that copyrights in them have been left to languish, large subsets of orphan works - such as those described in the examples given below-are likely to have been created for non-economic reasons. ${ }^{74}$ As such, a work's orphan status should at least trigger an inquiry into whether its orphaning is connected to the motivations behind its creation.

This is an important question to consider because many incentives to create are unlikely to be injured by allowing fair use. Nor, as Judge Leval points out, is copyright law designed to provide every incentive that might lead an author to create. Leval argues that the nature-of-work factor should favor the original creator more for works created for reasons "at the heart of the purpose of copyright" — such as those works prepared for publicationthan "in the case of a document written for reasons having nothing to do with the objectives of copyright law." 75 Kasunic further points out that inquiries into motivation and the author's "reasonable and customary expectations"76 for a work's scope of protection can illuminate the appropriate leeway for fair use. For example, more factual works are reasonably expected to enjoy "thinner" copyright protection than creative

71. See, e.g., Hofheinz, 146 F. Supp. 2d at 447-48.

72. See, e.g., Peter Letterese \& Assocs., Inc. v. World Inst. of Scientology Enters., 533 F.3d 1287, 1313-14 (11th Cir. 2008).

73. See id.

74. For some orphan works, of course, orphan status will be less informative on this point. Some orphans were created originally as commercial works, and have simply lost commercial value or had other misfortunes befall them over time. Courts should therefore consider the "orphan" aspect of a work's nature along with other characteristics in order to best analyze the work's orphan status under the nature factor.

75. Leval, supra note 48, at 1117.

76. Kasunic, supra note 53 , at 541. 
works; thus, a creator's copyright-based motivations are likely to be less affected by unpermissioned use of a factual work than of a creative work. ${ }^{77}$

To illustrate, Judge Leval uses the memorable example of an extortion note demanding "[p]ay me by Friday or I'll break your goddamn arms" ${ }^{\text {"78 }}$ as a work that would require no copyright incentives to stimulate creation or, indeed, any encouragement that copyright ought to provide. ${ }^{79}$ As such, the extortionist neither needs copyright-based incentives nor has cognizable "reasonable expectations" of ownership rights to protect, ${ }^{80}$ and the scope of fair use should be correspondingly broad. While Judge Leval's extortion note is a somewhat fanciful example, orphan works residing in library and archive collections provide abundant real-world examples of the same principles.

For example, research libraries are replete with academic works created and published, not primarily to profit from copyright, but to share knowledge, find truth, and advance the scholar's reputation and career; ${ }^{81}$ and with special collections that contain business records, personal correspondence, and many other items that were not prepared with copyright protection in mind. The Prelinger Archives, Internet Archive, and subjectmatter archives like the LOC American Memory projects and the Civil Rights Movement Veterans project collectively preserve and make accessible a wide variety of ephemera, including corporate training films, ${ }^{82}$ military propaganda ${ }^{83}$ home movies, ${ }^{84}$ amateur snapshots, ${ }^{85}$ advertising copy, ${ }^{86}$

77. Id. at $541-42$.

78. Leval, supra note 48, at 1116-17.

79. Id. at 1119 .

80. See Bill Graham Archives v. Dorling Kindersley Ltd., 448 F.3d 605, 612 (2d Cir. 2006) (quoting Leval, supra note 48, at 1117).

81. For one discussion of some academic authors' self-described incentives, see Academic Author Objections to Plaintiff's Motion for Class Certification at 1, Authors Guild, Inc. v. Google, Inc., Case No. 05 CV (S.D.N.Y. Feb. 13, 2012):

We write scholarly works on a regular basis. Our primary motivation in preparing these works is to share the knowledge we have cultivated with other scholars and interested members of the public. Although we are not indifferent to revenue streams we receive from books that we publish, the main reward we wish to attain from our intellectual labors is the satisfaction of contributing to the ongoing dialogue about issues of concern to us and, perhaps as an added bonus, a reputation for excellence in scholarship among our peers. A number of us have made some or all of our academic work available on an open access basis through Creative Commons licenses and the like.

82. Eric J. Schwartz, Founding Director/Board Member, National Film Preservation Foundation, Panel at Berkeley Orphan Works Conference: Who Wants to Make Use of Orphan Works and Why?, at slide 6 (Apr. 12, 2012) (slides available at http://www.law.berkeley.edu/files/paul_schwartz.pdf).

83. Id. 
meeting minutes, ${ }^{87}$ letters,${ }^{88}$ brochures,${ }^{89}$ marketing materials, ${ }^{90}$ and countless other items. These examples were presumably made, respectively, to improve industrial processes, gain support and funding for military endeavors, record family experiences, sell products and services, memorialize organizational decisions, correspond, and advocate and inform, among other reasons-but not, in general, to reap economic gains made possible by copyright protection. Today, while the private value of these works may still be low, the societal value of these works is high.

At the recent conference on orphan works held at UC Berkeley, librarians and archivists gave especially trenchant examples of orphan works with high societal value and a low likelihood of having been made with copyright incentives in mind. Rick Prelinger of Prelinger Archives showed footage of "release" day at a World War II internment camp for American citizens and residents of Japanese descent. The smiles and waves of the interns as they leave the camp in military trucks contrasts with the societal shame of the moment. The filmmaker's motivation might have been bureaucratic record-keeping, or perhaps more general historical recordation; there is no way to know. Despite the film's present historical importance, the owner is long lost. Bruce Hartford of the Civil Rights Movement Veterans website showed a photograph of James Forman, head of SNCC, gazing out from within a Southern jail cell. The photographer's identity is unknown, but his motivations are fairly clear. Former SNCC workers recall that he was also a prisoner in the jail; SNCC workers were not allowed to photograph in the prison, so they passed him a camera and he took the picture in response to a request. ${ }^{91}$ In both cases, the fact that the works have been left orphans supports an analysis that the motivations which provided the impetus for creation bore a limited relation, if any, to copyright incentives.

Overall, although a number of orphan works in library and archive collections were likely created with commercial incentives in mind, another number-perhaps a substantial number-are likely to represent the result of

84. Id.

85. Hartford, supra note 4 , at slide 6 .

86. Prosperity and Thrift: The Coolidge Era and the Consumer Economy, 1921-1929, LIBRARY OF CONGRESS (Aug. 9, 1999), http://memory.loc.gov/ammem/coolhtml/coolhome.html.

87. Hartford, supra note 4 , at slide 6 .

88. Id. at slide 7 .

89. Hartford, supra note 4 , at slide 6.

90. Kenneth Crews, Director, Columbia Copyright Advisory Office, Panel at Berkeley Orphan Works Conference: Who Wants to Make Use of Orphan Works and Why?, at slide 7 (Apr. 12, 2012) (slides available at http:/ /www.law.berkeley.edu/11731.htm).

91. Hartford, supra note 4 , at slide 6 . 
a wide array of non-copyright-based motivations to create. While owners may stay connected to works for a variety of noneconomic reasons, such as reputational value or sentiment, it seems likely that noneconomic motivations to create, and the attendant lack of ongoing economic interest in the ensuing works, contributed to the orphaning of many of these works. As such, inquiry into characteristics of the works' natures - including the fact that they are orphaned-is likely to provide useful guidance to courts deciding whether or not the work was likely created in response to copyright incentives. While orphan status alone is certainly not sufficient to conclude that a work was created in response to non-copyright-based motivations, orphan status should at least suggest looking further.

\section{Other Characteristics of Works in Library and Archive Collections}

As described above, the orphan status of a work, considered in concert with other characteristics of the work's "nature," is likely to yield information that is useful to a fair use analysis. There are, however, other reasons for courts to consider the nature of these works carefully in any fair use analysis. Many orphan works housed in libraries and archives are likely to exhibit additional characteristics of "nature"-for example, being highly factual rather than creative - that would likely weigh in favor of fair use irrespective of orphan status, and in addition to any evidence that inquiring into the work's nature presents about the author's motivation to create. In his HathiTrust order, for example, Judge Baer cited the fact that, on the whole, the HathiTrust Digital Library contained only about nine percent "prose fiction, poetry, and drama." 92

While the relevant characteristics will obviously vary from work to work and from collection to collection, one might expect to find a wide range of characteristics that would be considered favorable to fair use in library and archive collections. The scholarly works mentioned above will often be more factual than creative in nature, and this is (perhaps surprisingly) true of most other works in libraries as well. ${ }^{93}$ Special collections and subject-matter based archives contain large amounts of material, such as the ephemera described above, that have little economic value but a great deal of historical and cultural value. Many of these works, such as those in the subject-matter-

92. Authors Guild, Inc. v. HathiTrust, No. 11 Civ. 6351, slip op. at 18. Of course, this set is not a perfect proxy for "creative" work in the collection, but it is a suggestive indication.

93. A recent study of post-1923 works in WorldCat shows that fiction only makes up about eight percent of library holdings. See Brian Lavoie \& Lorcan Dempsey, Beyond 1923: Characteristics of Potentially In-Copyright Print Books In Library Digital Collections, 15 D-LIB MAG. (Nov./Dec. 2009), available at http://www.dlib.org/dlib/november09/lavoie/11lavoie.html. 
based American Memory collections, derive a significant portion of that value from the fact that they are contained within a curated collection; these works would be much less valuable on their own. ${ }^{94}$ The rare, obscure, or ephemeral works contained in library and archive collections would likely never be available to the public if it were not for those organizations' missions to collect, preserve, and provide access to them. ${ }^{95}$ All of these observations stem from considering the characteristics of these works in more detail than is generally done in fair use cases, lending further credence to Leval's and Kasunic's argument that the nature-of-work factor should be carefully considered.

In sum, serious inquiry into the "nature" of orphan works in library and archive collections is likely to reveal useful information about the appropriate breadth for fair use in any given dispute. Courts would be well-served by considering the nature-of-work factor carefully in the case of orphan works being digitized and made available by libraries and archives. In each example given above, consideration of the work's orphan status and other evidence of the motivations behind its creation and its creator's "reasonable and customary" expectations for its protection" could help courts analyze the equities under $\int 107$. For orphans, the equities will often weigh in favor of allowing preservation, access, and dissemination under fair use, as copyright incentives are unlikely to be damaged by the use of works that were not created in response to those incentives in the first place. And as noted above, inquiry under the nature-of-work factor is likely to provide insight into the best analysis under $\int 107$ 's fourth factor-"the effect of the use upon the potential market for or value of the copyrighted work," ${ }^{, 97}$ to which we turn next.

\section{The Market-Harm Factor and Orphan Works}

One of the most important factors that courts consider when analyzing fair use is the effect that the defendant's use will have on markets for the copyrighted work. ${ }^{98}$ This factor's importance stems from its close connection

94. For example, one set of meeting minutes may hold little interest, but a series of meeting minutes that reveal an organization's development over time may have high historical value.

95. It is important to note here that many works in special collections are likely to be unpublished. See supra note 70 and accompanying text (discussing the weight given in the fair use analysis to a work's unpublished status).

96. Kasunic, supra note 53, at 541.

97. 17 U.S.C. $\int 107(4)(2010)$.

98. Harper \& Row, Publishers, Inc. v. Nation Enters., 471 U.S. 539, 566 (1985); Matthew Sag, Predicting Fair Use, 73 OHIO ST. L.J. 47, 63-64 (2012); Beebe, supra note 49, at 616-18. For some time, lower courts applied the Supreme Court's discussion of the market 
to the incentive theory underlying U.S. copyright law. A use that does not harm the potential market for a work does not diminish the incentive to create that copyright provides, and is more likely to be fair use. ${ }^{99}$ Where the defendant's use of a copyrighted work harms an actual or reasonably foreseeable potential market for the work, incentives may be damaged, and the market factor will likely weigh against fair use. ${ }^{100}$

The fourth factor is an obviously salient factor in evaluating the fair use defenses as to orphan works. Orphan works are unusual in that they represent a truly complete market failure. ${ }^{101}$ Where there is no locatable owner with whom to transact-in other words, where one party to any transaction is simply missing ${ }^{102}$ - there cannot be a negative effect on the market for the work because no market can arise. ${ }^{103}$ Accordingly, while the potential societal benefit of transactions may be great, they cannot realistically occur.

factor in Harper \& Row, 471 U.S. at 566 ("This last factor is undoubtedly the single most important element of fair use.”). See, e.g., Sega Enters. v. Accolade, Inc., 977 F.2d 1510, 1523 (9th Cir. 1992); Princeton Univ. Press v. Michigan Document Services, Inc., 99 F.3d 1381, 1385 (6th Cir. 1996). Such an approach, however, could undermine the overall purpose of $\int 107$ 's protections for free expression and other salutary values, and the Court clarified its approach in Campbell v. Acuff-Rose Music, Inc., 510 U.S. 569, 577-78 (1994) (stating that "[t]he task is not to be simplified with bright-line rules," and "[a]ll [factors] are to be explored, and the results weighed together, in light of the purposes of copyright"). Since then, the importance of the "purpose of the use" has grown and solidified. See Bill Graham Archives v. Dorling Kindersley Ltd., 448 F.3d 605, 608-12 (2d Cir. 2006); see also Kelly v. Arriba Soft Corp., 336 F. 3d 811, 818-20 (9th Cir. 2002).

99. Sony Corp. v. Universal City Studios, Inc., 464 U.S. 417, 450 (1984) (noting that "a use that has no demonstrable effect upon the potential market for, or the value of, the copyrighted work need not be prohibited in order to protect the author's incentive to create").

100. The leading articulation of this reasoning is the Second Circuit's in American Geophysical Union v. Texaco Inc., 60 F.3d 913, 929-31 (2d Cir. 1994).

101. For another example of market failure in the copyright context, see Wendy Gordon, Fair Use as Market Failure: A Structural and Economic Analysis of the Betamax Case and its Predecessors, 82 Colum. L. REV. 1600, 1621 (1982). Gordon writes:

When a new use for copyrighted works becomes available to the public, market mechanisms may take time to develop. At early stages of use, the transaction costs that would be involved for a user to purchase permission to use, or for the copyright owner to seek enforcement against nonpaying users, might well exceed whatever gain the parties might otherwise expect from the transaction. A custom therefore may develop under which users proceed without permission.

Id.

102. Identifying orphans may, of course, be challenging. Assuming, however, that a reasonable search has been made for the owner, market failure can reasonably be assumed.

103. For a discussion of the possibility of creating a market of sorts through a collective licensing scheme, see infra notes 126-144 and accompanying text. 
Given this, harm to an owner's market from a follow-on use is vanishingly unlikely for true orphans. This circumstance should weigh heavily in favor of fair use where libraries and archives plan to digitize orphans. It also prompts two further observations. First, in order to create reasonable certainty that the market failure is as profound as asserted, ${ }^{104}$ orphans must be properly identified. ${ }^{105}$ Second, where orphans are properly identified and the purpose of the use is appropriate, a licensing scheme for orphan works is not only unnecessary under the fair use doctrine, but would represent a highly inefficient misallocation of resources. ${ }^{106}$

\section{B. MARKET HARM}

In considering the likelihood of harm to the market for a copyrighted work, courts consider both what the relevant market or markets for the work might be, and whether the defendant's use of the work is likely to cause harm to those markets. Broadly speaking, courts weigh the market-harm factor in favor of fair use where no relevant market exists or where the defendant's use does not invade a relevant market. Not all theoretically possible markets are relevant to the analysis; in the leading case on this point, the Second Circuit explains that "only traditional, reasonable, or likely to be developed markets" should be considered. ${ }^{107}$ In formulating this test, the Second Circuit followed the Supreme Court's descriptions of relevant markets as "only those that creators of original works would in general develop or license others to

104. For non-orphans, the transfer of rights needed to make a socially desirable use may naturally occur through negotiation and mutual agreement between the user and the copyright holder. See Gordon, supra note 101, at 1615. Note, however, that, while it may not be as complete if works are not true orphans, there may still be substantial market failure in the form of transaction costs that substantially outweigh the benefits of transacting, especially for older or obscure works, and especially for mass digitization projects. See, e.g., id. at 1628-30 (discussing transaction costs as a barrier where otherwise a market would function effectively); Samuelson, supra note 36, at 2614 (noting that "another important factor [weighing against copyright claims in Field v. Google, 412 F. Supp. 2d 1106 (D. Nev. 2006)] was the exceptionally high transaction costs that Google would have incurred if it had to seek and obtain permission for every copy its web crawlers made of Internet content.”).

105. See U.S. COPYRIGHT OFFICE, supra note 8 , at 8 (discussing the consensus view that orphans should be designated where an owner is either unidentifiable or unlocatable after a "diligent search").

106. See infra text accompanying notes 116-23; Ariel Katz, The Orphans, the Market, and the Copyright Dogma: A Modest Solution for a Grand Problem, 27 BERKELEY TECH. L.J. 1285 (2012); Randal C. Picker, Private Libraries and Orphan Works, 27 BeRKELEY TeCH. L.J. 1259 (2012).

107. Am. Geophysical Union v. Texaco Inc., 60 F.3d 913, 930 (2d Cir. 1994). 
develop" 108 and "the normal market for a copyrighted work." "109 Courts have found a lack of "traditional" or "normal" markets where, for example, the use is critical ${ }^{110}$ or otherwise transformative, ${ }^{111}$ or where a license to the work in an appropriate format is not offered for a reasonable price. ${ }^{112}$ Where licenses are readily available for the defendant's use, on the other hand, a viable relevant market is likely to exist. ${ }^{113}$

Courts are less likely to find market harm where a market fails to form or has socially harmful defects, such as inordinate transaction costs or negative externalities. ${ }^{114}$ Markets can fail for a wide range of reasons. A classic

108. Campbell v. Acuff-Rose Music, Inc., 510 U.S. 569, 592 (1994) ("The market for potential derivative uses includes only those that creators of original works would in general develop or license others to develop.’”.

109. Harper \& Row, Publishers, Inc. v. Nation Enters., 471 U.S. 539, 568 (1985) (fourth factor concerned with "use that supplants any part of the normal market for a copyrighted work”) (quoting S. Rep. No. 94-473, at 65 (1975)).

110. See, e.g., Campbell, 510 U.S. at 592 ("[T] he law recognizes no derivative market for critical works.").

111. Bill Graham Archives v. Dorling Kindersley Ltd., 448 F.3d 605, 614-15 (2d Cir. 2006).

112. Authors Guild, Inc. v. HathiTrust, No. 11 Civ. 6351, slip op. at 20 (rejecting argument that a claimed potential market for mass digitization of library books showed harm under the market factor where the claimed potential market was 'conjecture'); Cambridge Univ. Press v. Becker, 863 F. Supp. 2d 1190, 1237 (N.D. Ga. 2012) ("For loss of potential license revenue to cut against fair use, the evidence must show that licenses for excerpts of the works at issue are easily accessible, reasonably priced, and that they offer excerpts in a format which is reasonably convenient for users.").

113. See, e.g., Harper \& Row, 471 U.S. 539, 602-03 (weighing the fourth factor against fair use where the plaintiff was able to show a direct loss of licensing revenue for the infringed work and where there was substantial potential for damage to the market for first serialization rights even if direct loss had not been shown); Becker, 863 F. Supp. 2d at 1255 (weighing the fourth factor against fair use where a license in the correct digital format was readily available); United States v. Am. Soc'y of Composers, Authors \& Publishers, 599 F. Supp. 2d 415, 432-33 (S.D.N.Y. 2009) ("The existence of these markets [for derivative works of original ASCAP music] militates against a finding of fair use.").

114. See, e.g., Sony Corp. v. Universal City Studios, Inc., 464 U.S. 417, 451-55 (1984) (holding that plaintiffs did not show home time-shifting harmed the market); Kelly v. Arriba Soft Corp., 336 F. 3d 811, 821-22 (9th Cir. 2002); Becker, 863 F. Supp. 2d at 1290 ("[A]bsence of a ready market shifts the factor four analysis to favor fair use."); Field v. Google Inc., 412 F. Supp. 2d 1106, 1122 (D. Nev. 2006) (holding there was no evidence a "market for licensing search engines to access Web pages through 'cached' links" existed or was likely to develop); Time Inc. v. Bernard Geis Assocs., 293 F. Supp. 130, 146 (S.D.N.Y. 1968). Courts do not necessarily discuss such cases in terms of "market failure," but commentators have organized them under this rubric; see, e.g., Samuelson, supra note 36, at 2544-46, which provides one of the most important frameworks for understanding fair use in the literature. The foremost theorist of market harm in fair use cases is Wendy Gordon, whose seminal article critiquing the Ninth Circuit's decision in the Betamax case and offering a market-based test for fair use, and the subsequent expansion and clarification of her initial 
example is a market in which transaction costs are too high for the parties to gain from negotiating a socially beneficial transaction, resulting in no transfer at all. ${ }^{115}$ Other problems that can cause markets for copyrights to fail range from effects that arise from "priceless" interests in reputation (for, say, a copyright owner whose work is parodied) or speech (for the parodist), ${ }^{116}$ to a failure by the market to adequately compensate for positive externalities (generated by, for example, a scholar who develops new knowledge). ${ }^{117}$ Whether a market has truly failed may be contested; if transaction costs are high, an additional inquiry might be required in order to decide whether this

theory by both Professor Gordon and other commentators, stand as the most complete discussion available. Gordon, supra note 101. See, e.g., Christopher Buccafusco \& Christopher Sprigman, Valuing Intellectual Property: An Experiment, 96 CORNELL L. REV. 1, $42-44$ (2010); Wendy J. Gordon, Fair Use Markets: On Weighing Potential License Fees, 79 GEO. WASH. L. REV. 1814 (2011) [hereinafter Gordon, Fair Use Markets]; Wendy J. Gordon, Excuse and Justification in the Law of Fair Use: Transaction Costs Have Always Been Only Part of the Story, 50 J. COPYRIGHT SOC'Y U.S.A. 149 (2003) [hereinafter Gordon, Excuse and Justification]; Wendy J. Gordon, Market Failure and Intellectual Property: A Response to Professor Lunney, 82 B.U. L. REV. 1031 (2002) [hereinafter Gordon, Response]; Wendy J. Gordon, On the Economics of Copyright, Restitution, and "Fair Use": Systemic Versus Case-by-Case Responses to Market Failure, 8 J.L. \& INF. SCI. 7 (1997); Wendy J. Gordon, Asymmetric Market Failure and Prisoner's Dilemma in Intellectual Property, 17 U. DAYTON L. REV. 853 (1992); Raymond Shih Ray Ku, Consumers and Creative Destruction: Fair Use Beyond Market Failure, 18 BERKELEY TECH. L.J. 539 (2003); Lydia Pallas Loren, Redefining the Market Failure Approach to Fair Use in an Era of Copyright Permission Systems, 5 J. Intell. Prop. L. 1 (1997); Glynn S. Lunney, Jr., Fair Use and Market Failure: Sony Revisited, 82 B.U. L. REV. 975 (2002); Robert P. Merges, The End of Friction? Property Rights and Contract in the "Newtonian" World of On-Line Commerce, 12 BERKELEY TECH. L.J. 115, 130-35 (1997). Professor Gordon's initial three-part test for determining fair use under a marketbased analysis included the following elements: (1) presence of market failure; (2) transferring the use to the defendant is socially desirable; and (3) finding fair use would not substantially injure the copyright owner's incentives. Gordon, supra note 101, at 1614. Over time, Gordon expanded her initial analysis, and eventually decided that the third requirement should only apply in some cases. See, e.g., Gordon, Excuse and Justification, supra, at 183-84; Gordon, Response, supra, at 1031-32. However, even under the original, strict form of the test, orphan works present a clear market failure that should be remedied by fair use. See infra notes 115-125 and accompanying text.

115. See generally William M. Landes \& Richard A. Posner, An Economic Analysis of Copyright Law, 18 J. Legal STUd. 325 (1989); Richard Posner, ECONOMIC ANALYSis OF LAW (2d ed. 1977); R.H. Coase, The Problem of Social Cost, 3 J.L. \& ECON. 1 (1960).

116. See, e.g., Richard Posner, When is Parody Fair Use?, 21 J. LEgAL STUD. 67, 73-74 (1992) ("There is an obstruction when the parodied work is a target of the parodist's criticism, for it may be in the private interest of the copyright owner, but not in the social interest, to suppress criticism of the work. It is doubtful that this problem would be fully solved without an exemption from copyright protection even if the parodist could transform the social value of his work as criticism into private value and therefore compensate the copyright owner for the diminution in the latter's revenues as a result of the criticism.").

117. See, e.g., Gordon, supra note 101, at 1630. See also infra notes 118-125 and accompanying text. 
actually creates such a barrier to transfer that transfers will not occur or would only occur at a socially detrimental cost.

It is difficult to imagine a more complete form of market failure than that represented by orphan works. Not only are orphans not available on the market, but a market cannot form for lack of a rights-holder with whom would-be licensees could negotiate. For orphan works, no locatable owner exists, so no matter what the level of investment in trying to negotiate, no transaction will occur. Even for a possible set of works for which some owner exists somewhere-perhaps an oblivious or uninterested heir, or many oblivious or uninterested heirs_a markedly unreasonable outlay of transaction costs could be required in order to close a transaction. This set of works also represents a serious market failure. ${ }^{118}$ Consequently, markets around orphan works are decidedly unlikely to form, leaving little, if any, cognizable market harm that could arise from noncommercial efforts to preserve and provide access to such works. ${ }^{119}$

Digitizing and making orphans accessible to library and archive patrons, then, would seem highly unlikely to invade copyright owners' markets, favoring these activities under the market-harm factor. ${ }^{120}$ But would finding a fair use in the face of such a market failure nonetheless damage the copyright holder's incentives to create and disseminate new works in the future? While one can imagine that fear of being disassociated with one's rights in the future could disincentivize either creation of a work or, more likely, dissemination of the work to the public, this outcome also seems highly unlikely in the case of orphan works. Elsewhere in this issue, Professor Randal Picker explains how limited the likely incentive benefit of an orphan

118. Am. Geophysical Union v. Texaco Inc., 60 F.3d 913, 937 (2d Cir. 1994) (Jacobs, J., dissenting); Gordon, supra note 101, at 1618.

119. Compare markets for orphans, for example, to a possible market for the HathiTrust's uses of non-orphaned works in the HathiTrust Digital Library. In this case, Judge Baer found that:

Defendants offer substantial evidence that it would be prohibitively expensive to develop a market to license the use of works for search purposes, access for print-disabled individuals, or preservation purposes. Waldfogel Decl. ๆף 7, 22-24 (estimating that the costs of such a license as to the works in the HDL would be in the neighborhood of $\$ 569$ million and that the potential revenue generated would not cover these costs so it was not a "commercially viable endeavor").

Authors Guild, Inc. v. HathiTrust, 11 CV 6351 HB, 2012 WL 4808939, at *14 (S.D.N.Y. Oct. 10, 2012).

120. See, e.g., Campbell v. Acuff-Rose Music, Inc., 510 U.S. 569, 591-92 (1994); Becker, No. 08 Civ. 1425, 72-81; Hofheinz v. A \& E Television Networks, 146 F. Supp. 2d 442, 448-49 (S.D.N.Y. 2001). 
works licensing regime would be. ${ }^{121}$ And as explained, Section III.A, supra, some attributes likely to be contained in an orphan work's "nature"-less likely to be commercially valuable, more likely created for reasons other than economic gain-may indicate that incentives are unlikely to be damaged by repurposing the prototypical orphan work.

Where there is no cognizable harm to the market for a work, we should not expect incentives to create to be damaged, and should instead fear the loss of public benefit inherent in keeping the work from being put to beneficial purposes. As Justice Stevens pointed out in Sony v. Universal:

"[A] use that has no demonstrable effect upon the potential market for, or the value of, the copyrighted work need not be prohibited in order to protect the author's incentive to create. [This] would merely inhibit access to ideas without any countervailing benefit.... What is necessary [for a noncommercial use] is a showing by a preponderance of the evidence that some meaningful likelihood of future harm exists."

"[1]inhibit[ing] access to ideas without any countervailing [public] benefit" ${ }^{\text {"123 }}$ is precisely the type of social harm fair use seeks to prevent, and precisely the type of harm that can be prevented by library and archive digitization projects. Accordingly, the social harm created by the failure of orphan work markets is compounded by the positive externalities that would be generated by users who would "free" 124 the works and turn them to public benefit. Professor Wendy Gordon has identified two examples of positive externalities that are especially relevant here: the "significant 'external benefits" of teaching and scholarship, each of which enjoy significant support from libraries and archives. Gordon points out that through teaching and scholarship, "all of society benefits [by] having an educated citizenry and advances in knowledge," though educator salaries are relatively low and the benefits of communicating ideas may be nonmonetizable. ${ }^{125}$

Library and archive uses are especially likely to generate these and other positive externalities. Digitizing an orphan work and making it accessible makes it available to at least the patron base of a library, and in the cases of

121. Randal C. Picker, Private Libraries and Orphan Works, 27 BERKELEY TECH. L.J. 1259, 1280-82 (2012).

122. Sony Corp. v. Universal City Studios, Inc., 464 U.S. 417, 450-51 (1984).

123. Id. at 451 .

124. Loren, supra note 27 , at 1452-55.

125. Gordon, supra note 101, at 1630. See also Sony, 464 U.S. at 477-78 (Blackmun, J., dissenting) ("[Where] the scholar forgoes the use of a prior work, not only does his own work suffer, but the public is deprived of his contribution to knowledge. The scholar's work, in other words, produces external benefits from which everyone profits."). 
publicly accessible archives, to everyone. Such activities create spillover educational and cultural capital that accrues to the public in the form of learning and shared cultural and historical understanding. And of course any follow-on research, scholarship, or other social output that stems from the availability of orphan works represents further positive externalities attendant to those works becoming accessible.

\section{Collective or Other Centrally Managed Licensing}

Although no market for digitizing and making orphans accessible can naturally arise, it may be possible to create a licensing market through collective licensing or similar mechanisms. There would be some advantages of a licensing market, both because of the enhanced legal certainty of licensed uses for libraries and archives, and because a well-managed system could greatly limit the risk that a later-appearing owner would be left without compensation. ${ }^{126}$ A few such licensing systems already exist in other countries: Canada, India, Japan, South Korea, the United Kingdom, and Fiji. ${ }^{127}$ All of these schemes require some form of diligent search for the copyright owner ${ }^{128}$ and then delegate the right to issue licenses and set fees to a central authority. As another model, France recently adopted an extended collective license (ECL) regime that includes provision for unclaimed out-ofcommerce works; after six months' notice, the right to grant licenses accrues to the central licensing authority. ${ }^{129}$ In this and other ECL regimes, the

126. For arguments in favor of licensing for orphans, see, e.g., HARGREAVES, supra note 24, at 40 (recommending an extended collective license regime in the United Kingdom); Stef van Gompel \& P. Bernt Hugenholtz, The Orphan Works Problem: The Copyright Conundrum of Digitizing Large-Scale Audiovisual Archives, and How to Solve It, 8 POPUlAR COMM. 61 (2010).

127. Hansen, supra note 29, at 10 (describing regimes and collecting sources). Some of these schemes are extremely limited in nature. For example, the United Kingdom and Fijian laws give the Copyright Tribunal the ability to consent to "a person making a recording from a previous recording of a performance where the identity and whereabouts of a performer cannot be ascertained by reasonable inquiry." AgNieszka VeTUlani, The Problem of OrPHAN WORKS IN THE EU: AN OVERVIEW OF LEGISLATIVE SOLUTIONS AND MAIN ACTIONS IN THIS FIELD 10 (Feb. 2008), http://ec.europa.eu/information_society/activities/ digital_libraries/doc/reports_orphan/report_orphan_v2.pdf.

128. VetUlani, supra note 127, at 9-10. For example, the Copyright Board of Canada requires a hopeful user to "have made every reasonable effort to find the copyright owner" and the Japanese Commissioner of the Agency for Cultural Affairs may issue a license after "due diligence" fails to turn up the copyright owner. Unlocatable Copyright Owners, COPYRIGHT BOARD OF CANADA, http://www.cb-cda.gc.ca/unlocatable-introuvables/brochure2-e.html (last modified July 7, 2001); VETULANI, supra note 127, at 10.

129. Loi no 2012-287 du 1er mars 2012 relative à l'exploitation numérique des livres indisponibles du XXe siècle (1) [Law 2012-287 of Mar. 1, 2012 on the Digital Exploitation of Unavailable Books of the Twentieth Century], Journal OfFICIAL DE LA RÉPUBLIQUE FrANÇAISE [J.O] [OFFICIAL GAZETTE OF FrANCE], Mar. 2 2012, p. 03986, available at 
central licensing body is empowered to issue licenses for all copyright owners within its ambit, avoiding the need for a search for orphan owners.

Many of these systems cover orphans as extensions of broader schemes intended to reduce transaction costs and facilitate licensing of copyrighted works more generally ${ }^{130}$ and are thus directed at solving a broader set of problems than only those created by orphan works. And of course, American-style fair use is not a feature of the copyright law in the countries that have employed licensing systems. This fact undoubtedly makes such systems more attractive locally. Even in the United States, centralized licensing systems may be an appropriate approach to the stark transaction costs presented by the mass digitization of non-orphaned works, at least when those works are used in mass digitization projects that do not exhibit other features of fair use-for instance, where the project's purpose is a commercial one closely aligned with the copyright owners' original purposes in disseminating the work. ${ }^{131}$ For example, this might be a useful approach for books that are out of print due to lack of broad demand, but that are owned by someone with whom a license could be negotiated if transaction costs could be sufficiently diminished. ${ }^{132}$ In such a case, using a centralized licensing scheme to lower transaction costs enough to encourage new paid uses may be an efficient approach to encouraging mass digitization. ${ }^{133}$

http://www.legifrance.gouv.fr/jopdf/common/jo_pdf.jsp?numJO=0\&dateJO=20120302\&num Texte $=1 \&$ pageDebut $=03986 \&$ pageFin $=03988 \#$. See also Gillian Spraggs, France Guillotines Copyright, ACTION ON AUTHORS’ RigHTS (Feb. 28, 2012), http://blog.authorsrights.org.uk/ 2012/02/28/france-guillotines-copyright/ (providing a basic English translation of the law and links to commentary).

130. VETULANI, supra note 127 , at 8-13.

131. This is an intentionally narrow example - the purpose of the use is clearly highly important to whether licensing or fair use is the most appropriate option. Theoretically available copyright owners do not necessarily mean that licensing approaches are favored over fair use. Transaction costs, endowment effects, or other economic barriers may be sufficiently high, or social benefits may be sufficiently great for digitization uses to be fair beyond this context. See, e.g., Kelly v. Arriba Soft Corp., 336 F. 3d 811 (9th Cir. 2002) (reproduction of works to facilitate search engines, which require many millions or billions of unlicensed reproductions in order to function well, found to be fair use); Perfect 10 Inc. v. Amazon.com, Inc., 508 F.3d 1146 (9th Cir. 2007) (same); Field v. Google Inc., 412 F. Supp. 2d 1106, 1122 (D. Nev. 2006) (same). And, as discussed Part III.A, supra, the "nature" of the work as an orphan should be considered highly relevant in any fair use case. This Article is limited to a discussion of the digitizing of orphans by nonprofit libraries and archives; working out the parameters of when and if licensing is appropriate in other contexts is a topic for another paper. I do not take a position on that subject here.

132. There is some authority, however, suggesting that unavailability on the market should weigh in favor of fair use. See supra notes 68-72 and accompanying text.

133. Symposium, Collective Management of Copyright: Solution or Sacrifice?, 34 CoLuM. J.L. \& ARTS 589 (2011). This is not to say that collective licensing is necessarily the best solution 
For the library and archive uses of true orphan works discussed here, however, fair use is likely to prove a far more socially beneficial approach. ${ }^{134}$ The apparent benefits of certainty for the licensee and compensation for a later-appearing owner are likely to be far outweighed by the costs of a collective license system.

There are at least three sets of costs attendant to a centralized scheme for licensing orphans: first are the transaction costs required to bring licensees and copyright owners together and create a fair bargain; second are the administrative costs required to develop and manage the licensing regime; and third are the licensing fees. Because orphans, by definition, represent the failure of traditional licensing systems, some additional investment above and beyond that required by a naturally arising and functioning market would be required. This effect is exacerbated by the fact that a large portion of the costs of such a licensing system would likely constitute a substantial inefficient misallocation of resources, because most possible owners either will not exist or will be impossible to find at any price.

Considering each set of costs in turn illuminates the social harm that recognizing fair use would prevent. With regard to transaction costs, for true orphans, no amount of investment can result in a meaningful transaction, because the licensor is simply unavailable to complete it. While a generalized collective license could certainly be created, the possibility of such a license representing an actual connection between licensee and licensor is vanishingly small. No reasonable amount of investment in transaction costs is likely to achieve a match, even for works that could theoretically be "cleared" with enough expenditure. For true orphans, no amount of investment will produce a match, at all.

even for this situation. To be viable, any such system requires, at a minimum, the infusion of administrative resources, robust and effective oversight mechanisms, and safeguards to ensure that license prices are fair for both copyright holders and licensees and that resources are not misallocated. Further study is required, and full discussion is outside the scope of this Article. Commentators offer competing analyses of collective licensing approaches for different types of works. William W. Fisher III, Promises to KeEP: TeChNOLOGy, LAw, AND THE Future of ENTERTAINMENT 199-258 (2004); Jonathan Band, The Book Rights Registry in the Google Book Settlement, 34 COLUM. J.L. \& ARTS 671 (2011); Fred von Lohmann, Monetizing File-Sharing: Collective Licensing Good, ISP Tax Bad, Electronic Frontier Foundation (Mar. 20, 2008), https://www.eff.org/deeplinks/2008/03/monetizing-file-sharing-collectivelicensing-good-isp-tax-bad.

134. It is perhaps instructive that none of the countries that have adopted licensing systems have United-States-style fair use. See Peter Jaszi, Public Interest Exceptions in Copyright: A Comparative and International Perspective (presented at Correcting Course: Rebalancing Copyright for Libraries in the National and International Arenas), available at http:// correctingcourse.columbia.edu/paper_jaszi.pdf. 
Administrative costs present a similar issue: where the likelihood that the system can effectively transfer payment from licensees to licensors is as low as it is with orphans, the costs inherent in setting up and maintaining a licensing structure will nearly always be too high for efficiency to be achieved. For example, the Canadian system requires what is likely a quite costly ex ante review of requested orphan work uses. ${ }^{135}$ Under this system, the Copyright Board of Canada issued only 216 orphan work licenses between 1990 and 2007. ${ }^{136}$ (The rate did increase from an average of four to twenty-three licenses issued per year over that time period. ${ }^{137}$ ) While administrative costs will certainly vary by system, any system would have to be sufficiently robust to reliably offer transactions, even though the transactions are unlikely to pay copyright owners who have gone missing. Accordingly, both transaction costs and administrative costs represent potentially substantial misallocations of resources away from making orphans accessible, developing systems to prevent orphaning in the future, and other social benefits.

Finally, most licensing fees themselves would be misallocated from the putative licensee to the licensing system or another beneficiary. No owner exists to claim them, so even the lower fees that can be created by lowering transaction costs through centralized licenses are socially harmful. ${ }^{138}$ As noted, the possibility of a collective license representing actual connections between licensors and licensees is very low where the owner is unlocatable. None of the existing license regimes present a satisfactory solution to this problem. For instance, the Nordic ECL systems delegate decisions about fund distribution to the relevant Copyright Management Organization, ${ }^{139}$ and under the Canadian system the Copyright Board of Canada or collective society it tasks with distributing funds may use uncollected funds as is seen fit. ${ }^{140}$ While clear policies for disbursement and robust oversight procedures

135. Bernt Hugenholtz et Al., The Recasting of Copyright And Related RigHTS FOR THE KNOWLEDGE ECONOMY 187 (2006), available at http://ec.europa.eu/ internal_market/copyright/docs/studies/etd2005imd195recast_report_2006.pdf.

136. VETULANI, supra note 127 , at 10.

137. Id.

138. For a fuller discussion of this issue, see Picker, supra note 121.

139. Johan AXHAmn \& LuCie Guibault, Cross-Border Extended Collective LiCENSING: A SOLUTION TO ONLINE DisSEMINATION OF EUROPE's CULTURAL HERITAGE? 41 (2011), available at http://www.ivir.nl/publicaties/guibault/ECL_Europeana_final_report 092011.pdf.

140. The Copyright Board may set license terms, royalties, and disbursement. Copyright Act, R.S.C. 1985, c. C-42, s. 77 (Can.). The Board typically pays collected royalties to a copyright collective society "that would normally represent the unlocatable copyright owner." The collective society, in turn, pays the royalties out to the owner, should one 
could certainly help central authorities manage and disburse funds as effectively as possible, there is no way to address the fundamental inefficiency inherent in allocating purported license fees away from the copyright owner, and certainly no reason to think that a central authority would be more effective at picking socially beneficial disbursements than those who would make fair use of orphan works. ${ }^{141}$

There is one further cautionary note on licensing markets for orphans: the danger of undermining the application of fair use by, albeit artificially, creating a "market" for orphan works that could then be harmed by otherwise fair uses of the works - even though the overall social harm is great and the benefit to actual authors minimal. This "circularity" problem with the market-harm factor is familiar to both courts and commentators, who have wrestled with it for years. ${ }^{142}$ Licensing mechanisms have proven beguiling to courts considering market harm in the past, ${ }^{143}$ though recent case law has begun to clarify the issue, at least for transformative uses of works. ${ }^{144}$ Circularity is of particular concern with regard to the use of orphan works for educational or other socially beneficial purposes, because the social costs

appear within five years after the license expires; if no owner comes forward, fees are used as the collective society sees fit. Unlocatable Copyright Owners, supra note 128.

141. Indeed, the U.S. Copyright Office explicitly declined to recommend an approach like the Canadian system for this reason, COPYRIGHT OFFICE, supra note 8, at 83, 114, and the subsequent legislation proposed in Congress adopted a remedies-limitation approach instead. Orphan Works Act of 2006, H.R. 5439, 109th Cong., at 9 (2006); Orphan Works Act of 2008, H.R. 5889, 110th Cong., at 14 (2008); Shawn Bentley Orphan Works Act of 2008, S. 2913, 110th Cong., at 15 (2008).

142. I cannot do justice to the discussion in the space available here, but see, e.g., Bill Graham Archives v. Dorling Kindersley Ltd., 448 F.3d 605, 614-15 (2d Cir. 2006) ("“A] copyright holder cannot prevent others from entering fair use markets merely 'by developing or licensing a market.... " "); Am. Geophysical Union v. Texaco Inc., 60 F.3d 913, 937 (2d Cir. 1994) (Jacobs, J., dissenting); James Gibson, Risk. Aversion and Rights Accretion in Intellectual Property Law, 116 YALE L.J. 882, 947-51 (2007); Wendy J. Gordon, The 'Why' of Markets: Fair Use and Circularity, 116 YALE L.J. POCKET PART 371 (2007) (responding to Gibson); Gordon, Fair Use Markets, supra note 101 at 1826-34 (discussing the controversy more generally); Loren, supra note 114, at 38-39; Samuelson, supra note 36, at 2620 (discussing the controversy).

143. Princeton University Press v. Michigan Document Services, 99 F.3d 1381 (6th Cir. 1996), is a well-known example. In this case, a number of copy shops were persuaded to pay license fees for making educational course packets. Princeton University Press then sued a hold-out copy shop, which claimed fair use. Though others had operated without licenses for years, the court accepted that the licenses constituted market harmed by unlicensed use, and found against fair use. In dissent, Judge Merritt argued that this reasoning was problematic. Id. at 1397 (Merritt, J., dissenting) ("If the publishers have no right to the fee in many of the instances in which they are collecting it, we should not validate that practice by now using the income derived from it to justify further imposition of fees.").

144. See, e.g., Bill Graham, 448 F.3d at 614-15. 
inherent in a licensing system are so steep. It would be a poor outcome for the public and for copyright if a system that facilitated as few uses of orphans as the Canadian system does was then seen as a relevant market to be harmed by otherwise beneficial uses, limiting the application of fair use.

Overall, given the lack of benefit and the social cost of creating and maintaining them, licensing systems seem inadvisable where fair use supports making orphans accessible. Thus, courts should weigh the market-harm factor accordingly. For uses by nonprofit libraries and archives, which are both especially sensitive to cost and especially likely to generate positive externalities through their efforts to digitize orphans and make them available, the market-harm factor should weigh especially heavily towards fair use.

\section{NONCOMMERCIAL USE OF AND ACCESS TO ORPHAN WORKS VIA LIBRARIES AND ARCHIVES PROMOTES THE PROGRESS OF SCIENCE}

\section{A. The Purpose and Character of Nonprofit Library AND ARCHIVE USES OF ORPHANS FAVORS FAIR USE}

The first and often most important question considered in fair use cases is whether the purpose of the defendant's use furthers core societal goalssuch as learning, access to information, freedom of speech and expression, and innovation ${ }^{145}$ - or whether such use simply interferes with the rights of the copyright holder to exploit her rights in the work. Section 107 directs courts to consider "whether such use is of a commercial nature or is for nonprofit educational purposes." "146 Section 107 also provides a list of six favored uses: "criticism, comment, news reporting, teaching (including multiple copies for classroom use), scholarship, [and] research." 147 The purpose inquiry helps courts assess whether allowing a defendant's use would better fulfill copyright's purpose to promote Progress through the "creation and spread of knowledge" than would giving the copyright holder veto power over the use. Accordingly, the purpose factor constitutes a core component of fair use cases and, together with the market-harm factor, is one of the most influential factors in the analysis. ${ }^{148}$

145. Samuelson, supra note 36, at 2544-46 (organizing fair use cases into "policyrelevant clusters," including these).

146. 17 U.S.C. \$107(1) (2010).

147. Id.

148. Beebe, supra note 49, at 597-610; Sag supra note 98, at 55-61. 
Historically, there have been few cases analyzing libraries' and archives' purposes in copying works. As this Article was going to press, however, Judge Baer's decision in Authors Guild v. HathiTrust was published. This decision squarely addresses several purposes-full-text search, preservation, and access for users with print disabilities-for which the HathiTrust libraries are using the Google-scanned books in the Google Book Search corpus. ${ }^{149}$ As such, it sheds new light on how at least one federal district court views library purposes for mass digitization, and I have incorporated some of Judge Baer's findings into this analysis. ${ }^{150}$

The "creation and spread of knowledge" is central to the mission of nonprofit libraries and archives. This mission includes both preserving the knowledge contained within books, films, papers, and other artifacts, and spreading that knowledge. ${ }^{151}$ Consequently, when libraries and archives digitize orphan works and make them electronically available to patrons or to the broader public, they perform a variety of functions that are of a purpose and character likely to weigh steeply in favor of fair use under current doctrine. As discussed below, these libraries also perform functions for which there is little, or mixed, caselaw but that are so strongly in the public interest that they should weigh in favor of fair use nonetheless. Where the equities are close in weight, library and archives' salutary social functions, together with the lack of probable harm that would arise from making orphans available, should tip such functions toward fair use.

These functions can be divided into two sets: first-order uses and second-order uses. ${ }^{152}$ First-order uses are those undertaken directly by the library or archive. These uses include the initial digitization of the work, copying done for preservation, copying done to create indexes, catalogs, or other mechanisms that facilitate searching for and within the digitized works,

149. Authors Guild, Inc. v. HathiTrust, 11 CV $6351 \mathrm{HB}, 2012 \mathrm{WL}$ 4808939, at *2 (S.D.N.Y. Oct. 10, 2012).

150. Judge Baer's decision does not address orphan works. This is because the HathiTrust's nascent Orphan Works Program was stopped upon commencement of the litigation; Judge Baer thus held that the issue was not ripe for adjudication. Id. at *7-8. The decision instead addresses uses the HathiTrust made of books with known authors. Id.

151. About the Internet Archive, INTERNET ARCHIVE, http://archive.org/about/about.php ("Libraries exist to preserve society's cultural artifacts and to provide access to them."); AMERICAN LIBRARY ASSOCIATION \& ASSOCIATION OF RESEARCH LIBRARIES, THE ALA And ARL Position on Access and Digital Preservation: A Response to the SECTION 108 STUDY GROUP (Nov. 9, 2006), available at http://www.ala.org/advocacy/sites/ ala.org.advocacy/files/content/copyright/dmca/section108/sec108study/108ppfinal.pdf ("The mission of libraries is to preserve and provide access to information, regardless of format.").

152. Thank you to Dave Hansen for suggesting this helpful terminology. 
and copying done to place the works in historical and cultural context. Second-order uses are those supported by libraries' and archives' direct efforts but undertaken by others, usually patrons or members of the public, such as reading, viewing, conducting research, and producing scholarship or other secondary works.

To begin with first-order uses, most activities traditionally undertaken by libraries and archives further "nonprofit educational purposes" 153 and provide other "public benefit[s]," 154 putting them within the core of purposes that weigh in favor of fair use. Both Congress and the courts have recognized the public benefit inherent in preserving cultural materials. For example, Congress recognized an important public benefit in preserving films recorded on volatile nitrate stock, which it explicitly called out as a fair use. ${ }^{155}$ In Sundeman v. Seajay Society, ${ }^{156}$ the Fourth Circuit held that the complete reproduction of an unpublished, "fragile, seventy year old original manuscript" by a library was fair use, and "unquestionably served the "public benefit' and the 'development of art." "157 And in Authors Guild v. HathiTrust, Judge Baer held that preservation of books via the mass digitization of print copies was a fair use. ${ }^{158}$

153. 17 U.S.C. S 107(1) (2010).

154. Am. Geophysical Union v. Texaco, Inc., 802 F. Supp. 1, 27 (S.D.N.Y. 1992), aff'd, 60 F.3d 913 (2d Cir. 1994).

155. H.R. Rep. No. 94-1476, at 67 (1976) ("The efforts of the Library of Congress, the American Film Institute, and other organizations to rescue and preserve this irreplaceable contribution to our cultural life are to be applauded, and the making of duplicate copies for purposes of archival preservation certainly falls within the scope of 'fair use." "). More generally, of course, it also decided that preservation activities by qualifying libraries and archives justified a specific exception in $\$ 108$ of the Copyright Act. 17 U.S.C. \108(b) (2010) (covering some limited copying for preservation purposes of unpublished works); 17 U.S.C. \ 108(c) (2010) (excepting reproduction in some cases where the existing format in which the work is stored has become obsolete). In his recent article, The Impact of Substantial Compliance with Copyright Exceptions on Fair Use, Jonathan Band makes precisely this point, asking " $[\mathrm{w}]$ hat better indication could there be of the kinds of other purposes favored by Congress for fair use than the specific exceptions contained in the Copyright Act?" See Band, supra note 18, at 6 (exploring the relationship between the specific exceptions and fair use).

156. 142 F.3d 194 (4th Cir. 1998). As noted supra note 18, Congress' willingness to create exceptions for library preservation and other purposes most assuredly should not be considered evidence against those libraries' abilities to claim fair use, contrary to the Authors Guild's argument in Complaint, Authors Guild, Inc. v. HathiTrust, No. 11 Civ. 6351. Jonathan Band's analysis in Band, see supra note 18, is much more sensible.

157. Sundeman, 142 F.3d at 203.

158. Authors Guild, Inc. v. HathiTrust, 11 CV 6351 HB, 2012 WL 4808939, at *10 n.19 (S.D.N.Y. Oct. 10, 2012). Note that Judge Baer does state that, in his view, "[t]he argument that preservation on its own is a transformative use is not strong." Id. at 15 . However, he saw the "noncommercial nature of the use" as an important distinction from previous cases, 
Libraries and archives seek to preserve a wide variety of orphan works: books, photographs, sound recordings, visual works, ${ }^{159}$ rapidly disintegrating films, ${ }^{160}$ and websites, ${ }^{161}$ among many other materials. Preventing the loss of these cultural resources for future generations of readers, researchers, and learners clearly provides an important public benefit and serves a socially valuable purpose. With regard to orphan works specifically, preservation is likely of even greater value, as with no owner to preserve them or give permission for others to do so, orphans are at particular risk of being lost.

Libraries and archives also routinely promote learning and access to information by organizing materials, making them searchable, providing direct access to them, and offering productive enhancements such as curation, ${ }^{162}$ direct contextualization, or commentary. ${ }^{163}$ Organizing materials and facilitating information access through full-text searchable databases of these works, as search engines have done with images on websites, is likely to be considered transformative under current case law. ${ }^{164}$ In any case, this use is clearly a productive use that benefits the public. ${ }^{165}$ This prediction has been borne out by the HathiTrust decision, in which Judge Baer held that digitizing

especially Texaco, and cited the House Report, discussed supra note 155, in support of this analysis. $I d$.

159. Response of Library Copyright Alliance to Orphan Works Notice of Inquiry, Mar. 25, 2005, Comment OW0658 at 3-11, available at http://www.copyright.gov/orphan/ comments/OW0658-LCA.pdf.

160. See Schwartz, supra note 82, at slide 6; Access to Orphan Films, Response of Center for the Study of the Public Domain to Orphan Works Notice of Inquiry, Mar. 2005, Comment OW0596 at 1-4, available at http://www.copyright.gov/orphan/comments/OW0596CPD.pdf.

161. About the W ayback Machine, INTERNET ARCHIVE, http://archive.org/web/web.php (last visited Nov. 5, 2012).

162. Library Of CONGRess, Mission, supra note 2; About the Grateful Dead Archive, supra note 14.

163. See, e.g., Patriotic Melodies, supra note 5.

164. See Perfect 10, Inc. v. Amazon.com, Inc., 508 F.3d 1146, 1164-67 (9th Cir. 2007); Kelly v. Arriba Soft Corp., 336 F.3d 811, 818-20 (9th Cir. 2003); Field v. Google, 412 F. Supp. 2d 1106, 1118-19 (D. Nev. 2006).

165. See $i d$. Note that the works in question in each of these cases were publicly available on the Internet at the direction of the copyright holder, while libraries and archives would often be making the works available themselves. However, the lack of harm to missing owners of orphans is at least arguably analogous to the lack of harm to owners in these cases. See also New York Times, Inc. v. Roxbury Data Interface, Inc., 434 F. Supp. 217 (D.N.J. 1977) (holding that preparing a personal names index to a set of New York Times indices was fair use and stating, "[The index] appears to have the potential to save researchers a considerable amount of time and, thus, facilitates the public interest in the dissemination of information."). 
to create "superior search capabilities" was indeed transformative, and was fair use. ${ }^{160}$

Providing access to works-both in their original forms and in aggregated forms that allow for text-mining or other non-display uses ${ }^{167}$ helps fulfill copyright's most basic goal to "promote ... Progress" through the dissemination of knowledge. ${ }^{168}$ And adding contextualization and commentary to works repurposes them in a "productive" or "transformative" manner held by courts to be at the core of fair use's support for free expression. ${ }^{169}$ Each of these public benefits is again more valuable for orphans, which may otherwise languish in obscurity, and for which there is no existing original market to harm.

The first-order uses directly made by libraries and archives, of course, are also intended to support second-order educational, research, scholarly, critical, and other salutary uses made by library and archive patrons, including consumption for private learning. It is through these uses that copyright's dissemination goals are actually met. In organizing research, scholarship, and commentary into a cluster of "authorial" uses, for example, Professor Pamela Samuelson notes that such uses are ones "that copyright law welcomes in order to promote the ongoing creation and dissemination of new knowledge, thereby fulfilling the constitutional purpose of copyright law." ${ }^{170}$ Accordingly, these should comfortably be considered fair use, and courts tend to hold that they are. ${ }^{171}$ In the HathiTrust case, for example, Judge Baer specifically tied the defendant libraries' digitization program's support of learning by users with print disabilities to copyright's goals, citing these users' "unprecedented ability ... to have an equal opportunity to compete with their sighted

166. Authors Guild, Inc. v. HathiTrust, 11 CV 6351 HB, 2012 WL 4808939, at *11 (for first point), ${ }^{* 14}$ (for holding) (S.D.N.Y. Oct. 10, 2012).

167. See Matthew Sag, Orphan Works as Grist for the Data Mill, 27 BerkeLEY TECH. L.J. 1503 (2012).

168. Campbell v. Acuff-Rose Music, Inc., 510 U.S. 569, 575 (1994) (quoting U.S. CONST., art. 1, \8, cl. 8); EU ORPHAN WORKS DiRECTIVE, supra note 24; HARGREAVES, supra note 24, at 39; COMITÉ DES SAGES, supra note 24.

169. See, e.g., Campbell, 510 U.S. at 586-87; Bill Graham Archives v. Dorling Kindersley Ltd., 448 F.3d 605, 609 (2d Cir. 2006).

170. Samuelson, supra note 36, at 2545.

171. See Sundeman v. Seajay Society, 142 F.3d 194 (4th Cir. 1998) (fair to make full copy and use excerpts for scholarly commentary); Time, Inc. v. Bernard Geis Assocs., 293 F. Supp. 130 (S.D.N.Y. 1968) (fair use to publish sketches that recreate frames from the Zapruder Kennedy assassination film to illustrate a book offering alternative theories about the assassination); see also Samuelson, supra note 36, at 2546-78 (discussing uses that promote free expression and new authorship). 
peers." ${ }^{\prime 72}$ And while there is a dearth of authority regarding private, noncommercial_or "personal"-uses, there is some evidence that Congress thought such uses should be fair, ${ }^{173}$ and some courts have held them to be so. ${ }^{174}$ Where these uses do not damage a copyright holder's legitimate market, commentators have persuasively argued that they should be fair in order to protect legitimate and customary expectations in privacy, ${ }^{175}$ self-expression, ${ }^{176}$ and autonomy. ${ }^{177}$

Although educational and research uses are statutorily favored, the case law dealing with large-scale, institutional uses has less predictably found fair use than might be expected in light of copyright's purpose to promote learning. ${ }^{178}$ It remains to be seen whether the HathiTrust decision will have a broader effect, but it is a promising contrary example to this trend, given its close factual ties to libraries' actual practices and goals. In any case, when the work to be used is an orphan, courts need not worry about undermining publisher incentives to make works available, so the purpose factor should weigh more heavily in favor of fair use. In the principal research or educational use cases where fair use defenses have failed, orphan works were

172. Authors Guild, Inc. v. HathiTrust, 11 CV 6351 HB, 2012 WL 4808939, at *14 (S.D.N.Y. Oct. 10, 2012).

173. See H. Rep. 94-1476, at 74 (1976) (stating personal uses for education and research purposes may be fair); S. Rep. 94-473, at 63-66 (1975) (same). When considering personal uses, Congress was likely following the lead of other countries, many of which have explicit personal use exceptions built into their copyright laws. See, e.g., BMG Canada Inc. v. Doe, [2004] F.C. 488 (Can. Fed. Ct.) ("[D]ownloading a song for personal use does not amount to infringement.").

174. See, e.g., Sony Corp of America v. Universal City Studios, Inc., 464 U.S. 417, 454-55 (1984) (holding private noncommercial time-shift copying of television programs fair use); Recording Indus. Ass'n Am. v. Diamond Multimedia Sys. Inc., 180 F.3d 1072, 1079 (9th Cir. 1999) (characterizing place-shifting as "paradigmatic noncommercial personal use"). But see A\&M Records, Inc. v. Napster, Inc., 239 F. 3d 1004, 1019 (9th Cir. 2001) (distinguishing Sony and Diamond because "shifting in these cases did not also simultaneously involve distribution of the copyrighted material to the general public"); Metro-Goldwyn Mayer Studios, Inc. v. Grokster, Ltd., 545 U.S. 913, 931-32 (2005); see also Sega Enterp. Ltd. v. MAPHIA, 857 F. Supp. 679 (N.D. Cal. 1994) (rejecting Sony private use defense by commercial bulletin board service held as indirect infringer for facilitating up and downloading of Sega games by its users); Playboy Enterp., Inc. v. Frena, 839 F. Supp. 1552 (M.D. Fla. 1993) (rejecting Sony private use defense by commercial bulletin board service held as infringer for facilitating up- and downloading of Playboy bunny pictures by its users).

175. See Julie E. Cohen, The Place of the User in Copyright Law, 74 FordHAM L. REV. 347, 349 (2005); Jessica Litman, Lawful Personal Uses, 85 TEXAS L. REV. 1871, 1915 (2007).

176. See Joseph P. Liu, Copyright Law's Theory of the Consumer, 44 B.C. L. REV. 397, 415-20 (2003).

177. See Liu, supra note 176, at 406-11.

178. Samuelson, supra note 36, at 2545 ("Sharply divergent views on fair use exist in the educational and research use case law, and [these uses are least] predictable.”). 
not at issue, nor were library or archive programs directly considered. Publishers won challenges to for-profit copy shops selling coursepacks of articles and book chapters without permission, ${ }^{179}$ and to the for-profit company Texaco's scientists making archival copies of journal articles that publishers were willing to license. ${ }^{180}$ Yet, a fair use defense succeeded in a case challenging the National Institutes of Health and the National Library of Medicine for systematically photocopying scientific articles for the benefit of government medical and scientific researchers. ${ }^{181}$ And most analogously and recently prior to the HathiTrust decision, the trial court in Cambridge University Press $v$. Becker found that it was fair use for Georgia State University-an actual nonprofit educational institution, rather than a for-profit copyshopto copy "decidedly small" excerpts from books on behalf of faculty who wished to use such excerpts in teaching in the vast majority of challenged instances. ${ }^{182}$ The court further found that the arguments for fair use were strongest where an appropriate license at a reasonable price was not available. In the infringing instances, on the other hand, appropriate licenses were available.

Libraries' and archives' nonprofit digitization of orphans are likely to be much more analogous to Georgia State's or the NIH's activities, and much less like the copyshops' or Texaco's. Nonprofit libraries and archives' purposes - in short, to create public benefits - are more similar to those of government research agencies or nonprofit educational institutions than forprofit companies. In addition, like the instances of copying the court in the Georgia State case found most likely to be fair, there are no licenses available for orphans. In Unbundling Fair Uses, Professor Samuelson explains that institutional copying has been more controversial than "individual student or teacher copying," in part due to the fact that "publishers of educational materials have understandably worried that very liberal fair use rules would undermine sales of books, journals, and other materials and the development of new licensing markets." 183 Where the work in question has been orphaned, however, concerns about invading authors' or publishers' markets for educational and research materials are unlikely to arise.

179. See Basic Books, Inc. v. Kinkos Graphics Corp., 758 F. Supp. 1522 (S.D.N.Y. 1991); Princeton Univ. Press v. Michigan Document Services, Inc., 99 F.3d 1381 (6th Cir. 1996).

180. American Geophysical Union v. Texaco, Inc., 60 F.3d 913 (2d Cir. 1994).

181. Williams \& Wilkins v. United States, 487 F.2d 1345 (Ct. Cl. 1973), aff'd by an equally divided Court, 420 U.S. 376 (1975).

182. Cambridge Univ. Press v. Becker, 863 F. Supp. 2d 1190, 1232 (N.D. Ga. 2012)

183. Samuelson, supra note 36, at 2583-84. 
In addition, some courts consider it transformative or otherwise productive to employ works for a purpose "plainly different from the original purpose for which they were created." 184 As noted above, the purpose for which many orphans in library and archive collections were created is likely to be very different from the purposes to which libraries and archives wish to put them. Recall examples of works discussed above. These include items such as minutes from the SNCC May 1964 planning meeting, ${ }^{185}$ once a record of a group's organizational decisions and now a key document for understanding the historical features of the civil rights movement, or the film "U.S. Navy of 1915," made to "convince isolationists of the importance of building a strong American Navy," now also an historical document that would most likely be used for understanding early-twentieth-century propaganda rather than to persuade citizens of the Navy's importance. ${ }^{186}$ Judge Baer applied the concept directly in the HathiTrust case, noting that one new "purpose is superior search capabilities rather than actual access to copyrighted material" 187 and another is to "provide access to print-disabled individuals on an equal footing with sighted individuals." $188 \mathrm{He}$ also approvingly cited using works for "new methods of academic inquiry," such as humanities research based on text mining. ${ }^{189}$

Finally, the organization of and access to orphan works that library and archives can provide may enhance the value of those works directly-beyond the positive externalities generally expected from educational, scholarly, and other productive uses-by making them more available to discovery by those who would find new uses for them. As described above, this availability has obvious societal value, but it may have private value as well. In the rare case, owners - such as the oblivious or uncaring heirs posited in Section III.B, supra-may become aware, reappear, and take charge of the work. In the more likely case, other follow-on users may give the works new life.

Overall, the purposes to which libraries and archives are likely to put orphan works in their collections are likely to strongly favor fair use.

184. Bill Graham Archives v. Dorling Kindersley Ltd., 448 F. 3d 605, 609 (2d Cir. 2006). This analysis is also associated with the full-text search cases. See A.V. v. iParadigms, LLC, 562 F.3d 630, 640 (4th Cir. 2009); Perfect 10 v. Amazon.com, Inc., 508 F.3d 1146, 1165 (9th Cir. 2007); Kelly v. Arriba Soft Corp., 336 F. 3d 811, 819 (9th Cir. 2003).

185. See supra note 91 and accompanying text.

186. See supra note 90 and accompanying text.

187. Authors Guild, Inc. v. HathiTrust, 11 CV 6351 HB, 2012 WL 4808939, at *11 (S.D.N.Y. Oct. 10, 2012).

188. Id.

189. Id. (citing an amicus curiae brief by digital humanities scholars describing textmining-based historical research). 


\section{B. Library AND ARCHIVE Digitization OF ENTIRE ORPHAN WORKS OFTEN SHOUld Not Weigh Against FAIR UsE UNDER THE AMOUNT-AND-SUBSTANTIALITY FACTOR}

The final factor to be considered is "the amount and substantiality of the portion used in relation to the copyrighted work as a whole."190 In undertaking this analysis, courts consider both the actual quantitative amount used and the qualitative significance of it to the copyrighted work. ${ }^{191}$ Broadly speaking, the more a defendant uses of a copyrighted work, the less likely the use is to be deemed fair, and the less the defendant uses, the more likely the use will be deemed fair. ${ }^{192}$ However, digitizing and displaying entire orphan works for a variety of non-profit library and archive purposes should most often be considered neutral in a fair use analysis that reflects both the Supreme Court's guidance to connect the amount-and-substantiality factor to other factors and the approaches courts have taken in analogous cases.

While commentators have sometimes stated that it is generally not fair use to reproduce the entirety of a work, ${ }^{193}$ this suggestion is an oversimplified description of the case law that can lead to misunderstanding. Rather, as stated by the Supreme Court in Campbell v. Acuff-Rose, "the extent of the permissible copying varies with the purpose and character of the use," 194 and the most salient question is thus whether the amount used is "reasonable in relation to the purpose" for which the work is being used. ${ }^{195}$ Accordingly, courts have found copying entire works justified for a variety of purposes, from "time shifting" television shows, ${ }^{196}$ to creating search engine indexes, ${ }^{197}$

190. 17 U.S.C. $\int 107(3)(2010)$.

191. Campbell v. Acuff-Rose Music, Inc., 510 U.S. 569, 586-87 (1994); Harper \& Row Publishers, Inc. v. Nation Enters., 471 U.S. 539, 564-66 (1985).

192. Campbell, 510 U.S. at 574, 587; Harper \& Row, 471 U.S. at 561, 564-65.

193. See, e.g., NIMMER, supra note 54, \13.05[A][3] ("In general, it does not constitute a fair use if the entire work is reproduced.").

194. Campbell, 510 U.S. at 586-87.

195. Id. at 586. For an example of the detailed application of this principle to specific facts, see Warner Brothers Entertainment, Inc. v. RDR Books, 575 F. Supp. 2d 513 (S.D.N.Y. 2008), in which the court found that because the use in question was only "slightly transformative ... the amount and substantiality of the portion copied ... weigh[ed] more heavily against a finding of fair use." 575 F. Supp. 2d at 548-49. RDR Books is somewhat unusual in its focus on the amount-and-substantiality factor. See Beebe, supra note 49, at 61516.

196. Sony Corp. v. Universal City Studios, Inc., 464 U.S 417 (1984) (holding that "time shifting" was a fair use, but not explicitly analyzing the amount taken).

197. Perfect 10 v. Amazon.com, Inc., 508 F.3d 1146, 1166 (9th Cir. 2007) (concluding "that the significantly transformative nature of Google's search engine, particularly in light of its public benefit, outweighs Google's superseding and commercial uses of the thumbnails in this case"); Kelly v. Arriba Soft Corp., 336 F.3d 811, 820-22 (9th Cir. 2003) (concluding 
to building plagiarism detection programs for student papers, ${ }^{198}$ to reverse engineering software, ${ }^{199}$ to copying concert posters in order to display them on an historical timeline. ${ }^{200}$ In each of these cases, because using the entire work was reasonable or necessary to accomplishing a favorable purpose, the amount-and-substantiality factor was neutral in the analysis.

Properly considering the purpose and the amount factors together is especially important for library and archive digitization projects, which, by necessity, are very likely to reproduce entire works. In many, if not most, instances when libraries and archives digitize entire works, this digitization will be reasonable because it fulfills appropriate educational, scholarly, access to knowledge, and other socially beneficial purposes.

A few examples illustrate. In general, works cannot effectively be preserved in digital form unless they are digitized in their entirety, or as close to it as possible. The quality and accuracy of research and scholarship done using digitized materials could be compromised if scholars were limited to incomplete versions of works. For example, a historian comparing contemporary accounts of an event, a literature scholar analyzing a novel, and a scientist researching the development of a scientific theory over time each require access to entire works in order to effectively develop facts and draw conclusions. ${ }^{201}$ Research that depends on the computational analysis of large numbers of works-for example, the "non-consumptive,"202 "nonexpressive,"203 or "non-display" text-mining research developing as a methodology across a variety of disciplines — could not as effectively be done with partial digital copies. ${ }^{204}$ Similarly, educational purposes often require that

"that Arriba's use of Kelly's images as thumbnails in its search engine is a fair use"); Field v. Google, 412 F. Supp. 2d 1106, 1120-21 (D. Nev. 2006) (noting that "like the fair uses in Sony and Kelly, Google's use of entire Web pages in its Cached links serves multiple transformative and socially valuable purposes").

198. A.V. v. iParadigms, LLC, 562 F.3d 630, 642 (4th Cir. 2009).

199. Sega Enters. v. Accolade, Inc., 977 F.2d 1510, 1514, 1526-28 (9th Cir. 1992); Sony v. Connectix, 203 F.3d 596, 606 (9th Cir. 2000).

200. Bill Graham Archives v. Dorling Kindersley Ltd., 448 F.3d 605, 613 (2d Cir. 2006).

201. While scholars will make do with limited information if necessary, this approach can also limit the strength of their analyses and thus the value of their research - a price that fair use doctrine should not, and appears not to, require the public to pay. See, e.g., iParadigms, 562 F.3d at 642; Perfect 10, 508 F.3d at 1167-68; Kelly, 336 F.3d at 820-22; Field, 412 F. Supp. $2 \mathrm{~d}$ at $1120-21$.

202. Amended Settlement Agreement, Authors Guild, Inc. v. Google, Inc., Case No. 05 CV 8136 (DC) S 1.93 (S.D.N.Y. Nov. 13, 2009) (settlement as originally proposed), available at http://thepublicindex.org/docs/amended_settlement/amended_settlement.pdf.

203. See Sag, supra note 167 , at 1535-42.

204. For example, Matt Jockers uses text mining to analyze the differences among British, American, and Irish works' references to American Indians. See Matthew Jockers, 
substantial portions or entire works be accessible in order for learners to gain direct experience with the materials, make meaningful comparisons between sources, and the like. ${ }^{205}$ And regardless of whether each individual end user requires access to entire works, a library or archive is likely to need initially to copy entire works in order to support the varying needs of different end users. $^{206}$ The HathiTrust case again illustrates. Judge Baer affirmed the need to make entire copies for both searching and supporting end user needs-in this case, the needs of users with print disabilities. ${ }^{207}$

In addition to the connection between the amount-and-substantiality factor and the purpose factor, courts also connect the amount-andsubstantiality factor to the market factor. The overarching question is whether the defendant's use creates a potential market substitution for the copyrighted work; ${ }^{208}$ where relevant, using more of the copyrighted work is more likely to create a substitution effect. For orphan works, however, licenses are entirely unavailable-there is no functioning market in which a substitution effect can be felt, at all. ${ }^{209}$ Consequently, how much of a work is

Stanford University Literary Lab, Computing and Visualizing the 19th Century Literary Genome (Apr. 13, 2012) (slides available at http://www.law.berkeley.edu/files/Jockers.pdf). His conclusions would have little meaning without some confidence that the data is drawn from a reasonably large and representative collection of works. See Hugh Craig, Stylistic Analysis and Authorship Studies, in A COMPANIOn TO DigITAL Humanities (Susan Schreibman, Ray Siemens \& John Unsworth, eds., 2004) (noting the value of large representative samples for literary analyses); see also Nancy Ide, Preparation of Linguistic Corpora, in A COMPANION TO DigITAL HUMANITIES, supra (explaining the importance of developing a representative sample of works for linguistic analysis).

205. See, e.g., Terri Bays et AL., Code of Best Practices in FAir Use for OPENCOURSEWARE 11 (2009), http://www.centerforsocialmedia.org/sites/default/files/ 10-305-OCW-Oct29.pdf (giving the example of copyrighted materials that "are literally the subject of the course, rather than useful or incidental adjuncts to it or even examples or illustrations of the subject matter"); Arthur Marwick, Primary Sources: Handle with Care, in SOURCES AND Methods For FAmily And COMmunity Historians: A HandboOK (Michael Drake \& Ruth Finnegan eds., 1997).

206. For example, one patron may need to review only a chapter, or portion of a chapter, within a book; another patron may need to review two other chapters in the same book and so on. While each individual use is only a small part of the book, the library must digitize the entire book in anticipation of all likely future uses.

207. Authors Guild, Inc. v. HathiTrust, 11 CV 6351 HB, 2012 WL 4808939, at *12 (S.D.N.Y. Oct. 10, 2012).

208. See, e.g., Sony Corp. v. Universal City Studios, Inc., 464 U.S. 419, 449-50 (1984); Campbell v. Acuff-Rose Music, Inc., 510 U.S. 569, 589 (1994) (remanding "to permit evaluation of the amount taken, in light of . . considerations of the potential for market substitution"); A\&M Records, Inc. v. Napster, Inc., 114 F. Supp. 2d 896, 913 (N.D. Cal. 2000), aff'd in part, rev'd in part sub nom. A\&M Records, Inc. v. Napster, Inc., 239 F.3d 1004 (9th Cir. 2001).

209. See supra notes $98-144$ and accompanying text. 
reproduced should be considered much less relevant than in cases where there is a relevant extant market for the work-and reproducing entire works should more likely be considered "neutral" in the fair use analysis - than in cases where a functioning market for the copyrighted work exists. ${ }^{210}$ In Cambridge University Press v. Becker, for example, after considering both the amount-and-substantiality factor and the market factor, the court tended to find that Georgia State University could claim as fair use larger amounts of works for which licenses were not reasonably available. ${ }^{211}$ The same reasoning applies with force in the case of orphans, for which licenses are decidedly unavailable.

In sum, where libraries and archives are engaging in salutary purposes, and those purposes reasonably require reproducing entire orphaned works, the amount-and-substantiality factor should properly be considered neutral to the fair use analysis.

\section{FURTHER STRENGTHENING FAIR USE'S APPLICATION}

This Article has shown that nonprofit libraries and archives have strong arguments that digitizing orphan works in their collections and making them available for noncommercial, socially beneficial purposes are fair uses. Of course, the strength of this analysis will vary depending on the facts. A variety of considerations could strengthen fair use's application.

There are at least seven ways libraries and archives could strengthen the fair use arguments for digitizing orphans and making them available to patrons. ${ }^{212}$ Demonstrating good faith ${ }^{213}$ through record-keeping of reasonable

210. This is broadly in accord with Barton Beebe's empirical findings. Beebe, supra note 49, at 615-16.

211. The court individually considered seventy-five book excerpts that were digitized and placed on "electronic reserve." Where a license to digital versions was not readily available at a reasonable price and in a convenient format, the court found larger percentages to be fair use overall, after also considering the market-harm factor. Cambridge Univ. Press v. Becker, 863 F. Supp. 2d 1190, 1232 (N.D. Ga. 2012) ("Factor four weighs in Defendant's favor when such permissions are not readily available."). Where a license to digital versions was readily available, however, the court found that ten percent of small or unchaptered books, or one chapter of books with ten chapters or more was "decidedly small," and justified under the amount-and-substantiality factor; larger portions were not considered "decidedly small" and weighed against fair use. Id. at 72-81, 88-89.

212. Some of these suggestions are drawn from case law, and some from practical approaches taken by collections. With regard to the latter, they might best be considered "enhancements" to strengthen a fair use case; I am not arguing that they are necessary. Rather, I am drawing from an idea included in a recent set of practices deemed reasonable by American academic and research libraries. AssOCIATION OF RESEARCH LIBRARIES, ET AL., 
searches for owners could help establish that owners are indeed unlocatable, and thus unlikely to be harmed by the use. Giving public notice before actually making a digitized orphan available and offering an "opt out" for a period of time could both further demonstrate good faith and more importantly, help avoid inadvertently missing owners who were actually reasonably locatable. ${ }^{214}$ Offering digital copies only of physical works the library holds in its collection, and perhaps limiting the circulation of the physical work while the digital version is available, could help avoid the substitution effects considered under the market-harm factor. ${ }^{215}$ Focusing first on older orphan works in collections, which are both more likely to be orphans and less likely to support a market, might do the same. Offering works only within a library or archive's patron community, or within a broader research community, could maximize the chance that the use would support salutary purposes under the purpose factor and minimize the chance of economically harming possible owners. For freely available archives, such as online archives that are widely available to the public, limiting the types of uses patrons can make of orphan works to noncommercial, educational, or

Code of Best Practices in FAIR Use For ACADEMiC RESEARCH Libraries (2012), available at http://centerforsocialmedia.org/sites/default/files/documents/pages/code-ofbest-practices_arl_0.pdf.

213. "Fair use presupposes 'good faith' and 'fair dealing.' " Harper \& Row Publishers, Inc. v. Nation Enters., 471 U.S. 539, 562 (1985) (citation omitted). As such, courts sometimes explicitly consider the defendant's good or bad faith in fair use cases. See, e.g., id.; Peter Letterese and Assocs., Inc. v. World Inst. of Scientology Enters., 533 F.3d 1287, 1312 n.27 (11th Cir. 2008); MCA, Inc. v. Wilson, 677 F.2d 180, 183 (2d Cir. 1981); Field v. Google Inc., 412 F. Supp. 2d 1106, 1122 (D. Nev. 2006).

214. The University of Michigan/HathiTrust program has this feature. Orphan Works FAQs, UNIV. OF MICHIGAN LIBR., http://www.lib.umich.edu/orphan-works/faq (last modified July 24, 2012) (“[A] a list of potential orphans will be made available for ninety days before they are opened. If, at any time, a legitimate copyright holder approaches us we will remove their work from our pool of potential orphans."). From Michigan's first batch of 160 potential orphans, at least four have been identified as having living authors. See Orphan Row Update: Another Living Author, Two Books in Print, Literary Estates Held by Charities, Etc., The Authors GuiLd (Sept. 15, 2011), http://blog.authorsguild.org/2011/09/15/orphanrow-update-another-living-author-two-books-in-print-literary-estates-held-by-charities-etc/. Because the Orphan Works Program was not ripe to be adjudicated, this feature was not directly confronted in the HathiTrust litigation, discussed supra notes 17-23. As such, the court did not give guidance as to whether such a system does indeed enhance the legal strength of a fair use claim.

215. The planned University of Michigan/HathiTrust program also had this feature, limiting copies to be made available online to those in the library and further restricting access by keeping "the number of users permitted to view a given work limited at any one time to the number of copies held by" the Michigan library. Authors Guild, Inc. v. HathiTrust, 11 CV 6351 HB, 2012 WL 4808939, at *2 (S.D.N.Y. Oct. 10, 2012). 
otherwise fair uses ${ }^{216}$ could achieve the same goal. And of course, "taking down" or licensing a work if a licensing market develops and an owner appears could both demonstrate good faith and limit harm to the owner.

\section{CONCLUSION}

In sum, fair use has some significant advantages over other approaches through which libraries and archives could make publicly beneficial uses of orphan works. First, a robust fair use defense for such uses of orphans could prevent a substantial societal misallocation of resources. Under fair use, there is no need to pay socially wasteful license fees for works that are not on the market, and for which an owner is unlikely to exist. Further, there is no need for users to obtain ex ante permission from a review board or a collecting agency, and no need for the public to invest in developing such a system, significantly reducing administrative and transactional costs.

Second, fair use, as a judicially managed, case-by-case doctrine, has the flexibility to allow for change over time. As libraries and archives discover the best ways to search for owners, preserve works, and make them available to the public, and as new uses develop over time, courts can evaluate whether the changes fit within the parameters of fair use. And perhaps most importantly, allowing fair use of orphans by libraries and archives helps fulfill copyright's critical purposes of promoting the dissemination of knowledge and supporting speech and free expression. ${ }^{217}$

Relying on fair use has, of course, its own limitations. Fair use is less likely to apply to some uses-such as the commercial sale of orphan works, or the making of commercial derivative works-that can be covered by legislative fixes or collective licenses. In order for a fair use analysis tailored to orphan works to be most applicable, orphans must be appropriately identified, but there are some challenges inherent in this process: searches must be effective in sorting orphans from non-orphans, but cannot be so

216. For an example of such a policy, see the Library of Congress' description of appropriate uses in its American Memory Collections. See, e.g., The Wilbur and Orville Wright Papers, supra note 14:

The Library of Congress provides access to these materials for educational and research purposes and makes no warranty with regard to their use for other purposes. Responsibility for making an independent legal assessment of an item and securing any necessary permissions ultimately rests with persons desiring to use the item.

Id.; see also American Women, supra note 13.

217. I agree with Professor Samuelson that speech and free expression interests are best considered separate, though related, interests. Samuelson, supra note 36, at 2544 n.39. 
costly or otherwise onerous as to undermine the benefits of relying on fair use in the first place.

The doctrine's case-by-case nature means that libraries and archives must make risk assessments about whether courts are likely to agree that specific practices constitute fair use, and there is always the possibility that a court would not agree, creating uncertainty. The Authors Guild v. HathiTrust case clearly offers some recent and useful guidance; at the same time, this case may be appealed, and cannot address all future possibilities. And, of course, finding out with complete certainty whether a given use that has not already been adjudicated as fair is indeed fair would require litigation. ${ }^{218}$ Perhaps most limiting of all is the fact that fair use, in the form analyzed in this

218. For a cogent argument why "complete certainty" is not the appropriate standard for libraries deciding whether or not to rely on fair use, see Kevin L. Smith, Copyright Risk Management: Principles and Strategies for Large-Scale Digitization Projects in Special Collections, RESEARCH LIBRARY ISSUES: A QUARTERLY REPORT FROM ARL, CNI, AND SPARC, no. 279 17-23 (June 2012), available at http://publications.arl.org/rli279/; see also Kenneth Crews, If you Cannot Find an Owner, COPYRIGHT AdvisORY OFFICE, COLUMBIA UNIVERSITY LiBrary, http://copyright.columbia.edu/copyright/permissions/if-you-cannot-find-the-owner/ (last visited Sept. 1, 2012). In addition, a small but growing number of scholars have recently challenged the assumption that fair use is unreliable due to its uncertainty, backing their assertions up with data. See, e.g., Beebe, supra note 49; Sag, supra note 98; Samuelson, supra note 36; Peter Jaszi \& Patricia Aufderheide, Reclaiming Fair Use: How to Put BALANCE BACK IN COPYRIGHT (2011). A number of user communities have recently felt more empowered to rely on fair use in light of Jazsi and Aufderheide's project to create community driven "best practices." See, e.g., Anthony Falzone \& Jennifer Urban, Demystifying Fair Use: The Gift of the Center for Social Media Statements of Best Practices, 57 J. COPYRIGHT SOC’Y USA 337 (2010); Michael J. Madison, Some Optimism about Fair Use and Copyright Law, 57 J. COPYRIGHT SOC’Y USA 351 (2010); but see Jennifer E. Rothman, Best Intentions: Reconsidering Best Practices Statements in the Context of Fair Use and Copyright Law, 57 J. COPYRIGHT SOC'Y USA 371 (2010). The practical availability of the fair use defense cannot be divorced from the question of remedies. How remedies are calibrated affects the risk assessment of a putative fair user-if high remedies create a large downside risk, then uncertainty in the outcome of the defense is more likely to prevent a possible fair user from going forward with a use. Similarly, lower remedies mean that a negative outcome carries with it a smaller downside risk, making it more likely that a possible fair user will move forward in the face of uncertainty. Congress has already protected certain users- "nonprofit educational institution[s], librar[ies], or archives"-from high statutory damages if they have a "reasonable grounds" for believing that a use is fair. 17 U.S.C. $\int 504(c)(2)$ (2010). This is an important feature for nonprofit libraries and archives making risk assessments and courts should be willing to apply this feature to all entities engaging in nonprofit library or archival work, not only traditional organizations. I have argued elsewhere that $\int 504(\mathrm{c})(2)$ 's protections should be extended beyond these narrow categories of users. Jennifer M. Urban, Updating Fair Use for Innovators and Creators in the Digital Age: Two Targeted Reforms (Public Knowledge Fair Use Whitepaper, Feb. 15, 2010), available at http://www.publicknowledge. org/fair-use-whitepaper; see also Katz, supra note 106. 
Article, is a nearly unique feature of U.S. copyright law and does not apply in other countries. ${ }^{219}$

As such, fair use cannot cover the entire landscape of uses people might make of orphan works, and other solutions under discussion might better address a variety of uses. But for the digitization projects of nonprofit libraries and archives in the United States, its benefits make fair use a powerful tool for freeing the orphans in their collections.

219. In recent years, however, some other countries have begun adding significant flexibility into their copyright regimes, including some fair-use-like provisions. See, e.g., Copyright Act, 5768-2007, 2007 LSI 34, 19 (2007) (Isr.), available at http://www.wipo.int/ wipolex/en/text.jsp?file_id=132095; Intellectual Property Code of the Philippines \185, Rep. Act 8293 (Phil.), available at http://www.wipo.int/wipolex/en/text.jsp?file_id=129343; Copyright Act, part III, div. 3 (2006) (Sing.), available at http://www.wipo.int/wipolex/ en/text.jsp?file_id=187736. Israel's provision, in particular, is very similar to United-Statesstyle fair use. It follows $\int 107$ exactly, except that it eliminates the reference to "whether such use is of a commercial nature or is for nonprofit educational purposes" under the first factor. Copyright Act, 5768-2007, 2007 LSI 34, 19 (2007-2008) (Isr.), available at http://www.wipo.int/wipolex/en/text.jsp?file_id=132095. The Philippines law is also very similar. Intellectual Property Code of the Philippines \185, Rep. Act 8293 (Phil.), available at http://www.wipo.int/wipolex/en/text.jsp?file_id=129343. 
